\title{
Recent Advancements in Plastic Packaging Recycling: A Mini-Review
}

\author{
Valentina Beghetto ${ }^{1,2, * \mathbb{D}}$, Roberto Sole ${ }^{1} \mathbb{D}$, Chiara Buranello ${ }^{1}$, Marco Al-Abkal ${ }^{1} \mathbb{D}$ and Manuela Facchin ${ }^{1}$ \\ 1 Department of Molecular Sciences and Nanosystems, University Ca'Foscari of Venice, Via Torino 155, \\ 30172 Mestre, Italy; Roberto.sole@unive.it (R.S.); chiara.buranello@unive.it (C.B.); \\ 870009@stud.unive.it (M.A.-A.); manuela.facchin@unive.it (M.F.) \\ 2 Crossing S.r.l., Viale della Repubblica 193/b, 31100 Treviso, Italy \\ * Correspondence: beghetto@unive.it
}

Citation: Beghetto, V.; Sole, R.;

Buranello, C.; Al-Abkal, M.;

Facchin, M. Recent Advancements in Plastic Packaging Recycling: A

Mini-Review. Materials 2021, 14, 4782. https://doi.org/10.3390/

ma14174782

Academic Editor: John T. Kiwi

Received: 22 July 2021

Accepted: 19 August 2021

Published: 24 August 2021

Publisher's Note: MDPI stays neutral with regard to jurisdictional claims in published maps and institutional affiliations.

Copyright: (c) 2021 by the authors. Licensee MDPI, Basel, Switzerland. This article is an open access article distributed under the terms and conditions of the Creative Commons Attribution (CC BY) license (https:// creativecommons.org/licenses/by/ $4.0 /)$.

\begin{abstract}
Today, the scientific community is facing crucial challenges in delivering a healthier world for future generations. Among these, the quest for circular and sustainable approaches for plastic recycling is one of the most demanding for several reasons. Indeed, the massive use of plastic materials over the last century has generated large amounts of long-lasting waste, which, for much time, has not been object of adequate recovery and disposal politics. Most of this waste is generated by packaging materials. Nevertheless, in the last decade, a new trend imposed by environmental concerns brought this topic under the magnifying glass, as testified by the increasing number of related publications. Several methods have been proposed for the recycling of polymeric plastic materials based on chemical or mechanical methods. A panorama of the most promising studies related to the recycling of polyethylene (PE), polypropylene (PP), polyethylene terephthalate (PET), and polystyrene (PS) is given within this review.
\end{abstract}

Keywords: waste valorization; plastic waste; circular economy; recovery; recycling

\section{Introduction}

In recent years, the health of our planet has become a problem of crucial importance, with plastic recovery and disposal being of primary relevance [1].

Since the introduction of Bakelite in 1907 by Leo H. Baekeland, the first fully synthetic polymer, the plastic industry has evolved to revolutionize the way we live [2-5].

Polymers and plastic products own their well-known ubiquity and massive use to their excellent chemical-physical properties, which guarantee light weight, low price, and endurance [6]. Thanks to their great versatility, plastics are among the most used materials and find applications in many industrial sectors such as packaging, automotive vehicles, construction, and electronic devices [1,7,8]. Worldwide, over $360 \mathrm{Mt}$ of fossil-based polymers are produced yearly, with an annual growth rate of $8.4 \%$, two times higher than world global gross growth rate of production over the same period [5] (Figure 1a). The European plastic converter demand in 2018 reached $51.2 \mathrm{Mt}$, mainly to produce polyethylene $(\mathrm{PE})$, polypropylene (PP), polyvinylchloride (PVC), polyethylene terephthalate (PET), and polystyrene (PS) (Figure 1b). These are mainly employed for packaging $(39.9 \%)$, construction $(19.8 \%)$, automotive vehicles $(9.9 \%)$, and electronic devices (6.2\%) [9] (Figure 1c).

A gradual switch to biobased plastics has been witnessed by the increasing use at an industrial level of alternative raw materials $[10,11]$ such as polylactic acid (PLA) [12], polybutyl succinate (PBS) [13,14], polyhydroxyalkanoate (PHA) [15-17], and polyethylene furanoate (PEF) [18-20], together with different composite materials produced from starch [21-24], CMC [25-30], wood [31,32], lignin [33,34], and many different agro-industrial wastes [35-37].

Nevertheless, $99 \%$ of plastics produced today are fossil-based polymers, and they will continue to play an important role in many manufacturing compartments for a long time. 
In fact, according to the 2020 European Bioplastics report, the EU total production capacity of biopolymers is expected to reach $2.45 \mathrm{Mt}$ by 2024 (Figure 2), which is far lower than the plastic market needs [38].

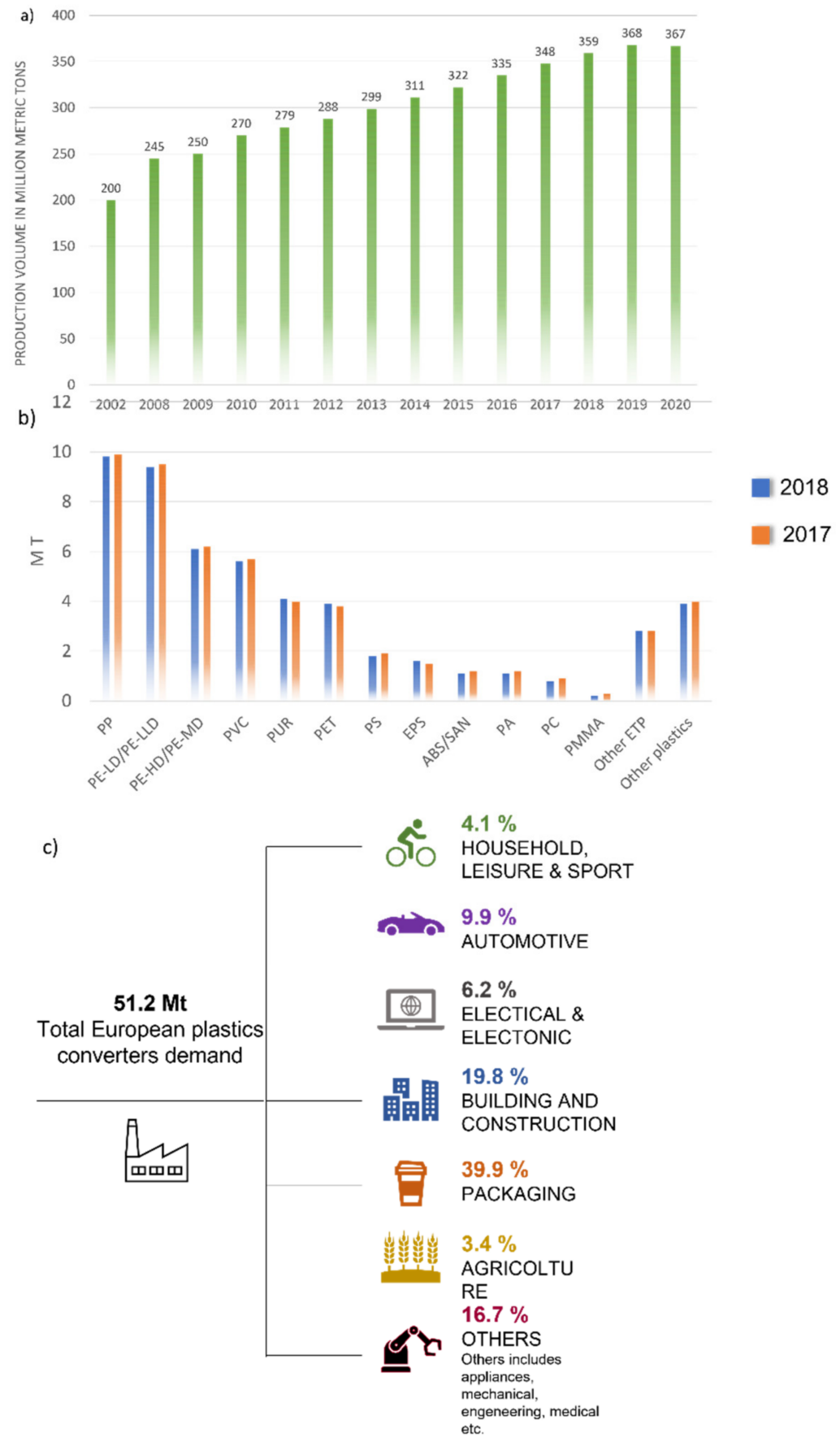

Figure 1. (a) World polymer production in metric tons; (b) distribution of main polymers produced; (c) 2018 European plastic converter demand and use.

The large gap between market demand and biobased plastics available today clearly shows the complexity of the problem and that all alternatives to approach the problem of plastic use and recycling must be pursued to reduce the environmental impact of polymers and plastic waste. In a recent article by Mendes and coworkers, the benefits of the use of bioplastics for the packaging industry were analyzed with the intent of delivering a guide for the design of more sustainable packaging to food packaging designers and 
producers [39]. The authors concluded that, from a climate point, the use of biobased plastics contributes to the generation of more sustainable food packaging compared to fossil-based ones; however, on the other hand, the relevance of some environmental problems originating from biobased plastics, such as eutrophication, use of water and pesticides, and effects on biodiversity, significantly reduces their environmental benefits.

Global Production Capacities of Bioplastics

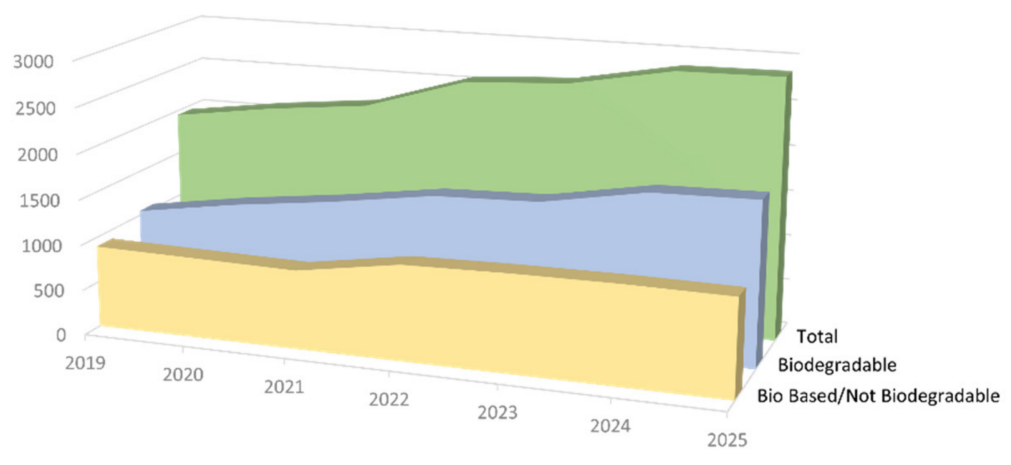

Bio Based/Not Biodegradable = Biodegradable = $=$ Total

Figure 2. Projection of world global production capacity of bioplastics by 2024 .

Additionally, fossil-based plastics are generally scantly biodegradable and accumulate in the environment, posing serious waste management problems. Over the last 65 years, approximately $8300 \mathrm{Mt}$ of fossil-based polymers were produced, $4900 \mathrm{Mt}$ of which were landfilled, incinerated, or dispersed in the environment $[5,40]$. Thus, oceans, animals, and humans are inevitably exposed to different sources of contamination from plastic waste [41-46]. Climate changes, environmental modifications, and health pandemics are becoming more and more frequent, showing that humanity will have to rethink its unsustainable growth $[47,48]$ by adopting a circular economy approach to resource consumption through eco-design, recovery, and recycling of polymeric materials with an integrated approach [49-53]. Circular economy is pushing toward a radical change in production and waste management to reduce water, waste, and energy consumption and to achieve zero-waste manufacturing cycles [10,54-57]. In this frame, European countries have developed different waste management systems and recycling techniques [58-64]. Nevertheless, a great part of post-consumer managed plastic is currently sent to incineration or landfill, while mismanaged waste is either discarded into the environment or is inadequately disposed of, potentially ending up in the ocean [46]. From 2006 to 2018, the amount of recycled post-consumer plastic waste doubled, reaching $32.5 \%(29.1 \mathrm{Mt})$, while $42.6 \%$ was used for energy production and 24.9\% was landfilled [9] (Figure 3).

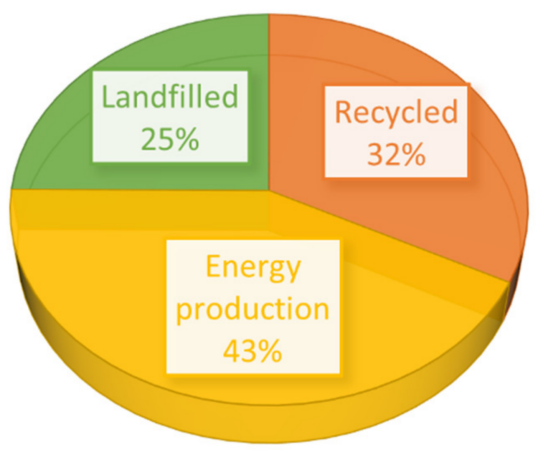

Figure 3. Reuse of recovered post-consumer plastic waste. 
In $2018,5 \mathrm{Mt}$ of plastic waste was recycled in Europe, $80 \%$ of which re-entered the EU as secondary materials, while the remaining $20 \%$ was exported outside the EU. The main industrial uses of recycled plastics in the EU are building and construction (46\%), packaging (24\%), agricultural applications (13\%), and others (17\%) [9].

Plastics may be subdivided into three categories: plastics in use, managed postconsumer plastic waste, and mismanaged plastic waste $[65,66]$. Managed plastic waste is generally disposed of by recycling, although a substantial gap exists between the quantity of plastic produced each year and the quantity of plastic thrown away since, depending on the type of product, there will be different storage and use times. Packaging products end their lifecycle generally in less than 1 year, while materials used for the construction and transport industry may last much longer. This means that the amount of waste produced each year is less than the amount of plastic in use. In 2015, $407 \mathrm{Mt}$ of primary plastic entered the use phase, while only $307 \mathrm{Mt}$ exited the use phase, with a consequent increase of $100 \mathrm{Mt}$ of plastic in use [5].

According to the literature, it was estimated that, in 2010, between 4.8 and $12.7 \mathrm{Mt}$ of plastics were leached into the ocean, predicting that, with inadequate waste management strategies, these numbers will increase by an order of magnitude by 2025 [46,67]. On this note, in January 2018, the European Commission issued the "European strategy for plastics in a circular economy" [68], including the ambitious target to make all plastics in EU recyclable by 2030. Soon after, in March 2018, China banned imports of plastic, generating a decrease in plastic waste export from EU of 39\%, thereby overloading the EU waste management system and incinerators [65,69].

To reduce the amount of plastic waste disposed in landfills or incinerated, there are two main strategies: the use of biodegradable biobased plastics (as mentioned above) [38,70] and recycling [71-74]. It should be reaffirmed that not all biobased polymers are biodegradable, while some fossil-based ones are, as clearly reported in Figure 4.

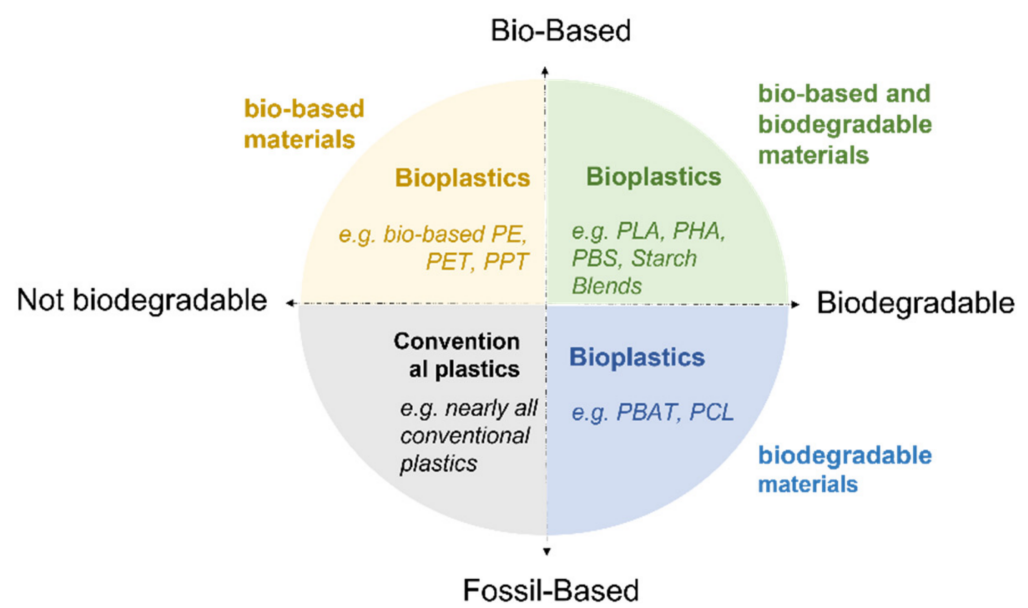

Figure 4. Examples of biobased and fossil-based polymers subdivided into biodegradable and not biodegradable.

Moreover, the recovery and recycling of biobased polymers is a relatively new issue and is still the object of studies compared to fossil-based polymers $[39,75]$; thus, different strategies will need to be put in place to implement the environmental sustainability of polymer manufacturing and recycling. According to the recent Circular Economy Package EU legislation and a paper by Briassoulis and coworkers, mechanical recycling is the best alternative for the valorization of both post-consumer fossil-based and biobased polymer waste, followed by chemical recycling [75,76].

The topic of sustainable manufacturing of plastics and packaging is so important that, from a research on Google Scholar using as key words "sustainable plastics", "recycled plastic", and "plastic recycling techniques", a total of almost 95,000 papers were published between 2019 and 2021. This mini-review intends to give an outlook on different mechanical 
and chemical recycling techniques, giving a general panorama of the state of the art and recent innovative solutions by focusing mainly on papers published in the last 12 months relevant to plastic packaging. The scope of the work is to give a general overview of most recent technologies for the recycling of post-consumer packaging waste (PP, LDPE, HDPE, PET, and PS) to be used as secondary materials for the manufacturing of different materials. Since it is possible that the EU will implement plastic recycling up to $100 \%$ by 2050, avoiding the use of virgin naphtha for its production, the use of plastic waste as a source of energy seems bound to assume a minor importance in the future, while recycling of polymers to produce high-value products will be of strategic importance. For this reason, techniques to produce energy from plastic waste will not be discussed in this mini-review. The authors believe that a good understanding of the possible alternatives to plastic recycling and valorization, together with the difficulties encountered in sorting and reprocessing of post-consumer plastic waste, should help the industry, as well as end users, to adopt more responsible behavior and, consequently, promote the introduction of environmentally sustainable solutions.

\section{Overview of Plastic Recycling Techniques}

The word recycling refers to a set of modifications and transformations (mechanical treatment, chemical treatment, or heating) required to recover feedstock from a previously processed polymer which can be reused by the industry $[73,77,78]$. Plastic recycling methods available today are classified in primary to quaternary processes $[79,80]$ (Scheme 1).

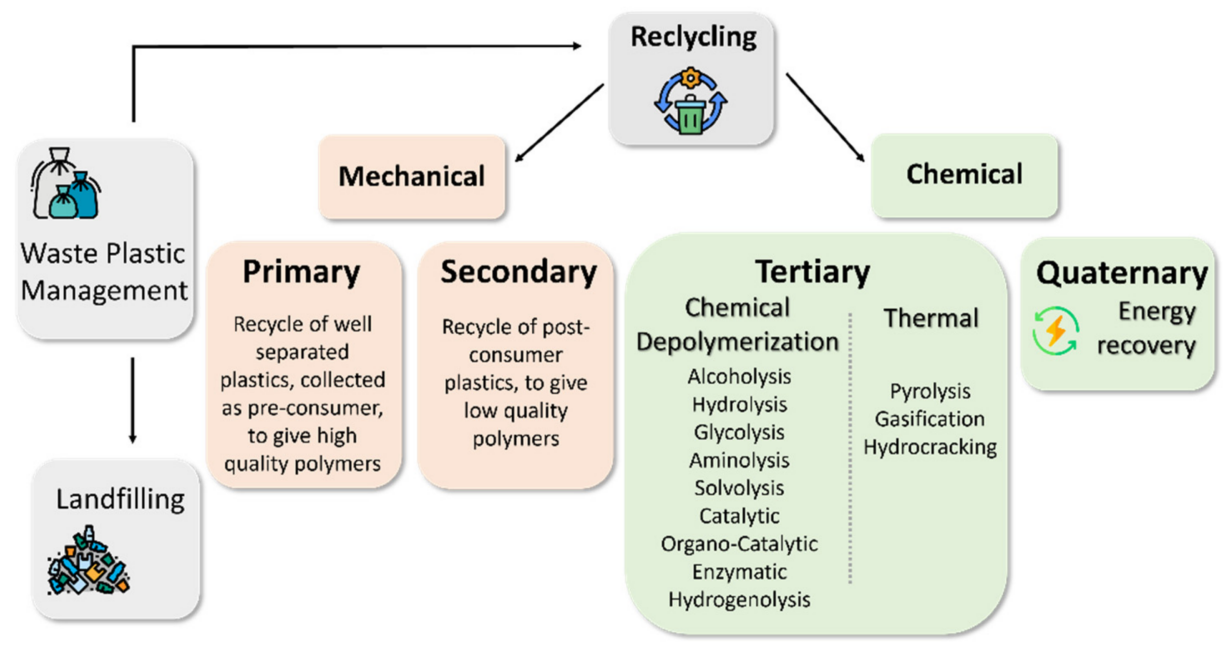

Scheme 1. Overview of plastic recycling techniques.

Specifically, primary processes allow recovering and recycling pre-consumer or pure polymers which can be reused for the same scope. Secondary processes start from recovered post-consumer polymeric waste, which is sorted, trimmed, and re-extruded, giving a product with reduced physical-mechanical characteristics compared to the starting polymer, which in most cases cannot be reused for the same scope. Primary and secondary recycling represents physical processes that can be repeated several times. Tertiary processes adopt chemical recycling starting from polymers which may no longer undergo mechanical recycling, while quaternary ones are used for energy production. Polymers and plastics sent to landfill (end-of-life plastics) lose their value and become waste.

Different techniques adopted for plastic waste separation, processing, and possible reuse as secondary materials depend on the type of waste recovered. A first important distinction should be made between thermoplastic and thermoset polymers. Thermoplastics are usually processed by extrusion, as these polymers melt when heated and harden when cooled. A great advantage of thermoplastics is that the extrusion process can be repeated many times. The most used thermoplastics are PP, PET, LDPE, HDPE, PVC, and PS. Adversely, thermosets may not be reprocessed by extrusion since, when heated, an 
irreversible chemical reaction takes place. Main thermoset plastics are polyurethanes (PUR), resins (epoxy, phenol-formaldehyde, and polyester), and vulcanized rubber, widely used by the automotive and electronic industry. The most abundant polymers in post-consumer waste are polyolefins (PP, LDPE, HDPE, PET, and PS) used for packaging [58,81,82], with a consumption of over $23 \mathrm{Mt}$ only in the EU in 2020.

\section{Primary and Secondary Recycling}

Mechanical recycling is the main and most widely used technology for plastic recycling, consisting of several steps, including collection, screening, automatic or manual sorting, washing, shredding, extrusion, and granulation [83-86] (Scheme 2). Mechanical recycling is classified as primary or secondary according to the type of starting material being processed. Primary recycling gives the highest-quality recycled polymers and starts from closed-loop recycled products such as PET bottles or byproducts collected by manufacturing industries as pre-consumer well-separated material.

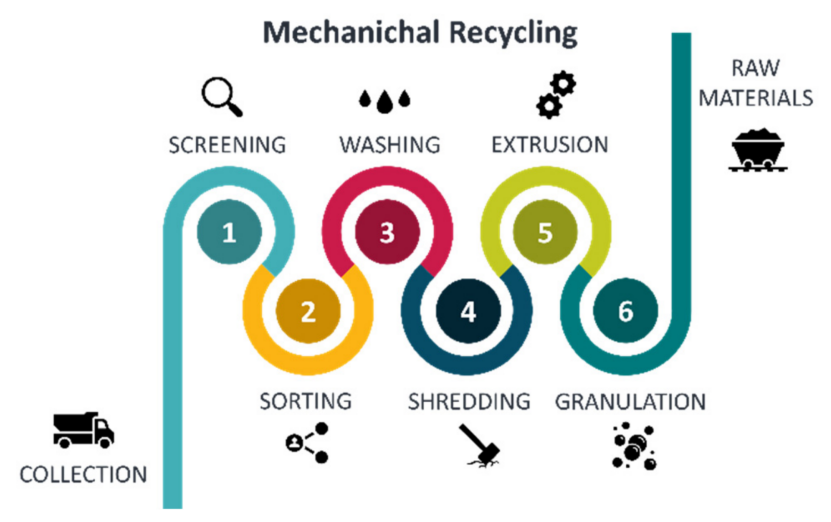

Scheme 2. General scheme of primary and secondary recycling processes.

Secondary processes instead recover post-consumer plastics and, therefore, generate lower-quality polymers. It must nevertheless be considered that, from an economic standpoint, these processes have a reduced complexity and overall limited costs, generating significant income and reduced $\mathrm{CO}_{2}$ production. According to the Ellen MacArthur foundation report, plastic production and incineration of plastic waste are estimated to produce over $400 \mathrm{Mt}$ of $\mathrm{CO}_{2}$ yearly $[87,88]$. Thus, recycled plastics can reduce fossil-fuel consumption and $\mathrm{CO}_{2}$ emissions. According to estimates by Rahimi and coworkers [89], the adoption of plastic waste recycling worldwide would allow saving about 3.5 million barrels of oil each year.

Mechanical recycling generally includes four main steps: (i) screening and sorting; (ii) shredding; (iii) washing and drying; (iv) melting and reprocessing (Scheme 2).

Screening and sorting of plastic waste is a fundamental step for the recyclability of the different plastics and the quality of the final polymer. This step is challenging, considering that the separation of mixed plastic waste often involves the combined use of different technologies $[90,91]$.

To achieve an adequate separation of a specific polymer within a flow stream containing many different components (plastics, as well as metals, paper, organic residues, and dirt), characteristics of the final product must be accurately considered such as purity and destination. This will allow defining the best separation strategy to achieve high selection. Important properties commonly employed for plastic separation are magnetic or electric properties, particle size, density, and color. Relying on these properties, many different separation techniques have been developed such as dry or wet gravity separation, electronic or magnetic density separation, flotation, and sensor-based sorting together with auxiliary segregation techniques such as magnetic or eddy-current separation. These segregation methods are briefly described, mainly focusing on recently implemented technologies for PE, PP, PET, and PS recovery. 
Gravity separation is a consolidated methodology that may be carried out in a dry environment (dry process) or in the presence of water (wet process) [63,92] (Figure 5a). Dry segregation techniques employ air classifiers or ballistic separators in which air is used as the medium to separate lighter materials from heavier ones. They can be positioned at the beginning of the process or at the end, to segregate end-of-life plastics from main plastic streams (Figure $5 b$ ). Wet gravity separation includes sink and float, jigging, and hydrocyclone techniques.

a)
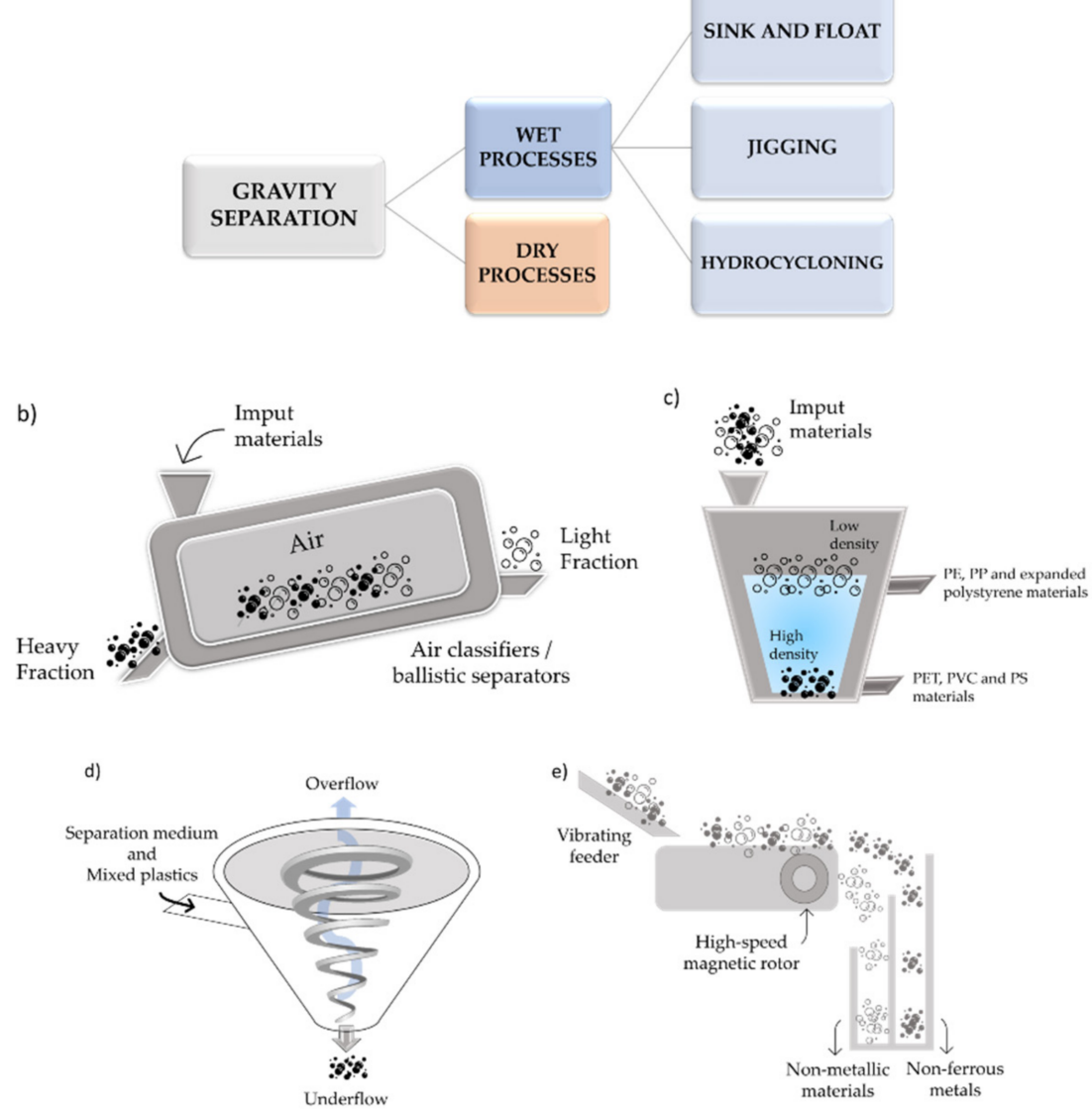

Figure 5. (a) Different methodologies of gravity separation; (b) dry segregation; (c) sink and float separation; (d) hydrocycloning; (e) eddy current separator.

With sink and float separation, polymers are separated into two different streams depending on whether they have a higher or lower density than water. Materials such as PET, PVC, and PS will sink, while others such as PE, PP, and expanded polystyrene will float (Figure 5c). This type of separation guarantees an effective first separation, but it is not adequate to produce high-quality secondary materials and needs to be combined with other separation techniques [93-95].

Zhang and coworkers developed a pretreatment of PET via preliminary $\mathrm{NaOH}$ and ethanol hydrolysis to promote plastic flotation. Optimal conditions allowed the quantitative recovery of highly pure PET fractions [96].

Heidarpour and coworkers reported the influence of microwave irradiation in the presence of chemical additives such as PEG-400, methylcellulose, or tannic acid on the float-sink behavior of polyoxymethylene, polycarbonate, and polyvinyl alcohol. According to this study, microwave irradiation reduced the contact angle values of tested plastic surface in the presence of chemical additives (depressant) by implementing their sink-float separation capacity, thereby increasing their hydrophilicity [97]. The authors mention the possibility of using this technology for whichever plastic material. 
Jigging is one of the oldest gravity separation techniques and is similar to dry gravity methods where, in most cases, water is used instead of air $[90,94]$. A water stream is pushed up and down by pistons, and plastics are separated mainly depending on their morphological and physical characteristics.

Hydrocycloning is based on centrifugal and centripetal forces together with the fluid resistance of different materials processed (Figure 5d). New trends in hydrocycloning separation focus especially on the recovery of precious metals from electronic device waste $[98,99]$, and it seems to be a very valuable tool for more sustainable separation of plastic waste from metals.

The eddy current separator is made of a high-speed magnetic rotor which generates an electric current, the so-called eddy current, used to remove nonferrous metals (aluminum and copper) from waste plastic, glass, and paper, among others (Figure 5e) [100]. These separators are generally located at the beginning of the recycling process.

With a separator and drum screen, plastics are fed into a large rotating drum where materials are separated by size, thanks to holes in the drum, so that only smaller particles pass through and are separated from larger ones.

Different gravity segregation methods were analyzed by Nie and coworkers for the sustainable recovery and recycling of high-value metals from waste printed circuit board (WPCBs) [101]. This study analyzed the dynamics and statics of gravity concentration methods. The settling velocity of three kind of particles was studied, demonstrating that the stratification by density is spontaneous and can achieve the lowest potential energy. The concentration of differently sized metal particles could be effectively enriched, and the metal purity increased from $56.5 \%$ to $68.2 \%$ for decreasing particle size, albeit with a modest decrease in yield (from $86.41 \%$ to $83.04 \%$ ). No recent papers were found for the use of innovative solutions for the recovery of PE, PP, PET, or PS by jigging, hydrocycloning, eddy current separation, and drum and different gravity segregation techniques, but they were reported to give a general overview of different separation technologies available.

Optical sensors are used for the characterization of plastic stream in a continuous manner where air jets allow for separation. Optical sensors may be subdivided in molecular spectroscopies and atomic spectroscopies [102], the prevalently used Raman spectroscopy (RS) [103], Fourier-transform infrared spectroscopy (FTIR) [96], near-infrared spectroscopy (NIRS) [104], and terahertz spectroscopy (THz) [105], and elemental spectroscopies such as laser-induced breakdown spectroscopy (LIBS) [106] and X-ray fluorescence spectroscopy (XRFS) [102].

Bobulski and coworkers implemented new portable devices for computer image recognition in combination with artificial intelligence for waste recognition and easy municipal waste separation. The devices were used both at home and in waste sorting plants, and they could be a very useful tool for an efficient and economically sustainable separation of plastic waste stream [107].

Most companies use a combination of different separation techniques to obtain sufficiently pure polymers from post-consumer plastic waste. The purity of the finished product depends on an adequate compromise between costs and benefits, and this leads to purities $\leq 95 \%$ which require further separation and purification steps. Sorting technologies reported above are generally inadequate for the separation of complex materials such as multilayered packaging or fiber-reinforced composites; therefore, these materials are generally incinerated for energy recovery or landfilled as end-of-life plastics.

Innovative recycling methods such as selective polymer dissolution were demonstrated to be efficient in extracting different polymers and fibers from multilayered films and composite materials [108]. In fact, Knappich and coworkers reported the efficient recovery and recyclability of epoxy and polyurethane resins from carbon fiber-reinforced plastics with different proprietary CreaSolv ${ }^{\circledR}$ formulations at a laboratory scale.

Multi-material plastic waste separation technologies are also being developed to enable a proper sorting of composites, which will generate new value streams to recover and recycle plastics which are today incinerated or landfilled [109]. Many approaches 
have been tested, for example, for the separation of polyester from cotton fibers to recycle textile waste. Solvent-based technologies are an interesting solution, with the possibility of selecting specific solvents which may solubilize either cotton or polyesters [110]. A crucial aspect for industrial success and applicability is the nature of the solvent in terms of volatility, flammability, toxicity, and recyclability [111].

Once the mechanical separation is complete, the materials are shredded by passing them through a system of rotating blades. The obtained flakes are then sorted by size with a grid, washed and dried, made ready for reprocessing by extrusion or agglomeration, and sold.

Agglomeration is generally used to reprocess plastic films which are cut in small pieces, heated by friction and water-cooled. The agglomerates are usually combined into plastic flakes and pelletized by extrusion. Agglomeration is highly energy-consuming and, therefore, less widespread [90].

Extrusion remains the most widely used method for processing both virgin and recycled plastic. Plastic flakes are fed into the extruder and pushed by a screw into a heated cylinder, thus melting the plastic. At the end of the extruder, a pelletizer cools and cuts the final polymer into pellets.

Both shredding and extrusion may lead to partial degradation of the polymer due to chain scission and thermo-oxidative reactions, reducing the polymer chain length and, consequently, its mechanical properties [112,113]. Moreover, impurities deriving from other packaging components further contribute to the diminished physical-mechanical characteristics of reprocessed plastics [104].

A detailed study was published by Eriksen and coworkers on the thermal degradation, processability, and mechanical properties of re-extruded PET, PE, and PP from post-consumer waste. PET is well suited for closed-loop recycling to meet bottle and food-grade PET quality, although moisture control is a key requirement when reprocessing PET into products. For this polymer, degradation, which generally occurs during recycling by extrusion, may be avoided by careful decontamination. The quality of reprocessed PE samples from non-food bottles strongly depends on the presence of impurities from other polymers and from lids and labels. PE reprocessing by extrusion suggested that closed-loop recycling may be achieved with selected PE bags with low levels of polymer cross-contamination. Adversely, PP reprocessed by extrusion showed low mechanical properties with large variations in impact strength, reducing possible applications of reprocessed PP. Thus, the heterogeneity of PP waste, even if food packaging is managed separately, as well as polymer degradation during recycling, represents crucial limitations for PP waste recycling [114].

A possible remedy to downgrading due to extrusion was reported for the first time by Wang and coworkers. The authors reported a process to modify polyolefins from postconsumer plastic waste via a one-step radical grafting and cross-linking process, producing covalent adaptable networks or CANs [112]. This procedure relies on the functionalization of polyolefins with polar reagents, which modify the properties of the starting material, thus imparting new characteristics such as wettability, printability, and compatibility with other polymers. Upcycling of LDPE from plastic bags was achieved by free-radical reaction in a twin-screw extruder in the presence of maleic anhydride and butanediol. PE-CANs showed higher solvent resistance, tensile strength, and modulus compared to virgin PE due to the presence of cross-linking bonds generated during the extrusion process. Upcycling of post-consumer plastic waste by reactive extrusion is an interesting area of research which will surely receive much attention in the future; however, characteristics of CAN polymers must be acquired to define new possible manufacturing applications [115].

\section{Chemical Depolymerization}

In addition to mechanical methods, recycling can be performed via chemical depolymerization $[111,116]$. 
Chemical recycling has great potential in the circular economy of plastics; it can close the loop by producing starting monomers from the polymers that may be reprocessed to produce high-value-added chemicals [70]. It is estimated that, by 2050 , almost $60 \%$ of plastic production can be based on recycled products [117]. Millions of euros are being invested to enhance chemical recycling and other cutting-edge technological solutions with the aim of producing 1.2 Mt of recycled plastic in EU by 2025 and $3.4 \mathrm{Mt}$ by 2030 [9].

Chemical recycling methods are classified according to reaction conditions into solvolysis (hydrolysis, methanolysis, and glycolysis), catalytic depolymerization, and enzymatic depolymerization $[83,84,118-127]$. Only main innovative solutions devised in the last year for plastic packaging chemical recycling are analyzed below i.e., PE, PP, PET, and PS.

\subsection{Solvolysis}

Solvolysis involves the breaking of the hydrolyzable bonds of a polymer in the presence of an alcohol or water. It is rather frequent that, to improve reaction conditions, product selectivity, and yield, catalysts are used to promote solvolysis reactions $[83,84,119,128]$.

\subsubsection{Hydrolysis}

Hydrolysis reactions perform better from an environmental point of view but require higher energy consumption compared to other solvolysis methods [129]. They may be carried out in neutral, acidic, or alkaline conditions.

Neutral hydrolysis of PET has long been known and is generally processed in the molten phase, at temperatures above $245^{\circ} \mathrm{C}$ with a water/PET $(w / w)$ ratio above 5.1/1. A further improvement in the rate of the reaction may be achieved via the addition of catalytic amounts of alkali metal acetates, organophosphorus compounds, or zeolites [128]. Recently, Colnik and coworkers reported hydrolytic recycling of colorless and colored PET bottles in sub- and supercritical water with temperatures between 250 and $400{ }^{\circ} \mathrm{C}$, in 1 to $30 \mathrm{~min}$. Highest yields in terephthalic acid (TPA) were achieved at $300{ }^{\circ} \mathrm{C}$ in $30 \mathrm{~min}$ with purities near to $100 \%$ [130] (Scheme 3).

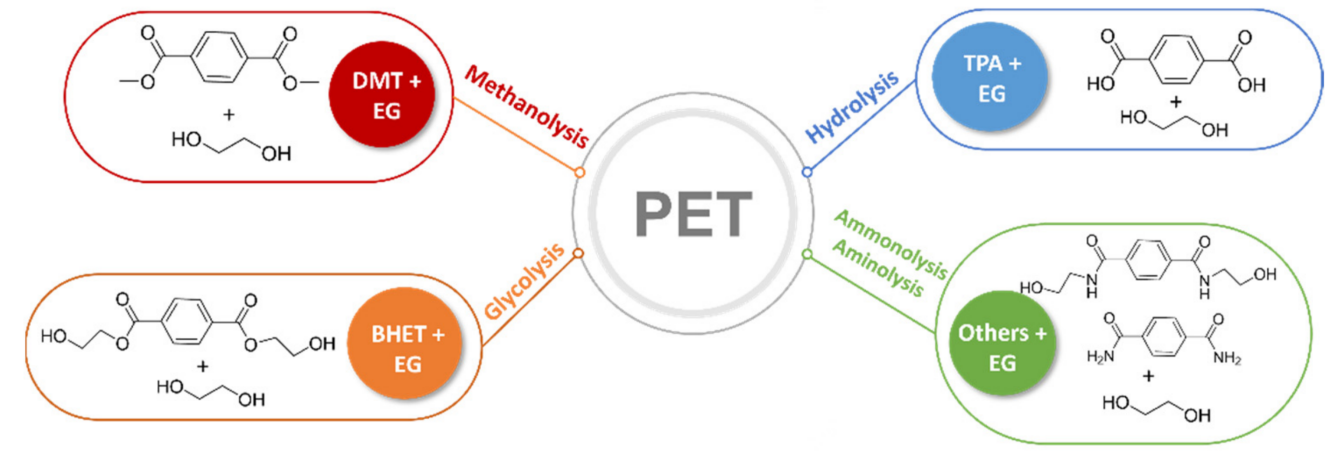

Scheme 3. PET chemical recycling routes and product desired.

Interestingly, according to the work by Stanica-Ezeanu and coworkers, sea salt is an efficient neutral catalyst promoting PET degradation; by means of a mathematical model, it was estimated that, in tropical regions, only 72 years are necessary for spontaneous complete degradation of PET to occur [131].

Acid hydrolysis of PET proceeds by polymer dissolution in concentrated acids $\left(\mathrm{H}_{2} \mathrm{SO}_{4}\right.$, $\mathrm{H}_{3} \mathrm{PO}_{4}$, and $\mathrm{HNO}_{3}$ ) and heating, leading to chain fragmentation at high temperature.

These processes have not been, to the best of our knowledge, the object of recent studies, probably due to their low environmental sustainability; therefore, they are not further discussed in this review.

Alkali-promoted glycolysis of PET has been widely reported using both inorganic and organic bases [132]. Due to the high quantities of alkali required and consequent environmental impact of the process, in this case, no innovative solutions were found in recent publications. 


\subsubsection{Methanolysis}

Methanol is widely used and is effective for the solvolysis of various polymers such as PET, polyamides, and polycarbonates. The majority of post-consumer recovered PET is currently reprocessed by mechanical recycling; however, this process leads to molar mass reduction and a consequent reduction in the physical-mechanical properties of the polymer, which is generally used to produce carpets (72\%) [70], along with a small percentage of PET for bottle production [129]. Moreover, the commercial appeal of mechanical recycled PET depends on the price of oil; thus, when oil is available at prices below $\$ 65$ per barrel, mechanically recycled PET is no longer competitive [70]. Chemical depolymerization to produce high-quality monomers and oligomers may be a solution to this problem.

The primary scope of PET chemical recycling is to regenerate TPA, dimethyl terephthalate (DMT), bis(2-hydroxyethyl) terephthalate (BHET), and ethylene glycol (EG) [133] or other chemical substances $[134,135]$ (Scheme 3).

Methanolysis of PET is generally a degradation process performed at high temperatures $\left(180-280^{\circ} \mathrm{C}\right)$ and pressures $(2-4 \mathrm{MPa})$, and the major products are DMT and EG [70,129], with high capital and operating costs. Recently, Pham and coworkers [124] developed a low-energy catalyzed methanolysis to convert PET into DMT at room temperature in the presence of $\mathrm{K}_{2} \mathrm{CO}_{3}$ as a catalyst. Despite the overall reaction time of $24 \mathrm{~h}$, PET resins were completely decomposed into monomers with high selectivity in DMT with $93.1 \%$ yield at $25^{\circ} \mathrm{C}$. 2-Hydroxyethyl methyl terephthalate (HEMT) and monomethyl terephthalate (MMT) were the major byproducts collected after the reaction (Scheme 4).

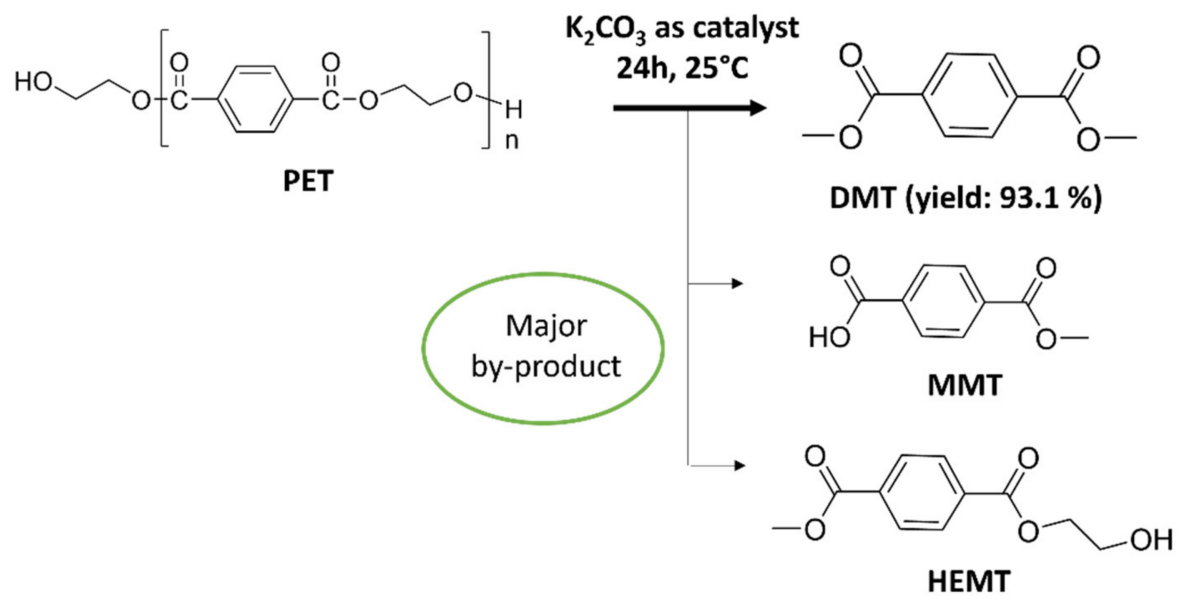

Scheme 4. Low-energy catalyzed methanolysis of PET.

Myren and coworkers described a new method for methanolysis of post-consumer PET waste in the presence of $\mathrm{NaOH}$ carried out in a microwave or electrochemical reactors. Under mild reaction conditions $\left(85^{\circ} \mathrm{C}, 40 \mathrm{~min}\right)$ overall yields in TPA of $65 \%$ were achieved under microwave irradiation [136].

Barnard and coworkers published a review in 2021 evaluating advantages and disadvantages of chemical recycling of PET based on the energy economy coefficient and environmental energy impact. Different technologies evaluated comprised neutral, acidic, or alkaline hydrolysis, enzymatic hydrolysis, solvolysis, glycolysis, and aminolysis. From the comparison of data collected, alcoholysis was the most energetically expensive process; moreover, the low boiling point of alcohols generally requires high-pressure reactors. On the contrary, methanolysis carried out in the presence of a nanodispersion of $\mathrm{ZnO}$ was found to be the least energetically expensive process for PET degradation, giving high-quality DMT $[129,137]$.

Additionally, Zhang and coworkers proposed a novel, simple and economic hydrophilic modification of PET by surface alcoholysis in the presence of ethanol and a sodium hydroxide water solution, which influenced the wettability of PET and promoted sink-float separation from hydrophobic PS, PVC, and PMMA [96]. 
Another very interesting example of the methanolysis of PET was achieved in the presence of an organocatalyst prepared from very simple reagents such as tetramethyl ammonium hydroxide and dimethyl carbonate, $\left[\mathrm{NMe}_{4}\right]^{+}\left[\mathrm{OCO}_{2} \mathrm{Me}\right]^{-}$, achieving good yields of DMT $(\leq 75 \%)$ in mild reaction conditions $\left(100{ }^{\circ} \mathrm{C}\right.$ and $4 \mathrm{wt} . \%$ organocatalyst) [138]. Nevertheless, long reaction times $(16 \mathrm{~h})$, solvents, and product purification were necessary. Alternatively, imidazolium metal-based ionic liquids (ILs) can achieve a comparable or even better performance than $\left[\mathrm{NMe}_{4}\right]^{+}\left[\mathrm{OCO}_{2} \mathrm{Me}\right]^{-}[139]$. Main ILs reported in the literature are depicted in Figure 6.<smiles>C[N+](C)(C)CCO</smiles>

[Ch][For]<smiles>CCCC(=O)[O-]</smiles>

[Ch][Bu]<smiles>C[N+](C)(C)CCO</smiles>

[Ch][OAc]<smiles>C[N+](C)(C)CCO</smiles>
[Ch][Cl]<smiles>CCC(=O)[O-]</smiles>
[Ch][Pro]<smiles>C[N+](C)(C)CCO</smiles>
[Ch][Mesy]<smiles>C[N+](C)(C)CCO</smiles>

Figure 6. Main ILs reported in literature.

\subsubsection{Glycolysis}

Glycolysis was also verified to be a promising alternative with moderate energy and environmental impact [129]. Glycolysis produces the BHET monomer, which is a good starting material for PET upcycling. As reported by Lalhmangaihzuala and coworkers, glycolysis of post-consumer PET waste may be efficiently promoted by heterogenous catalysts prepared from orange peel ash. Total depolymerization of PET was detected within $90 \mathrm{~min}$, producing BHET in 79\% yield. The catalysts were recovered up to five times without significant deactivation. This study opens the way to a highly environmentally sustainable approach to post-consumer plastic waste recycling [127].

Organocatalyst-assisted glycolysis is considered a new frontier for a green approach to plastic recycling in comparison to conventional organometallic complexes $[138,140]$. Wang and coworkers [141] reported a very promising study on the glycolysis of PET using 1,3-dimethylimidazolium-2-carboxylate as an organocatalyst, achieving complete depolymerization in less than $1 \mathrm{~h}$ at $180^{\circ} \mathrm{C}$, with up to $60 \%$ yield in BHET recovered by precipitation from the reaction mixture upon cooling.

Alternatively, Fuentes and coworkers reported the glycolysis of PET bottles to BHET in the presence of catalytic amounts of different metal oxides $(\mathrm{ZnO}, \mathrm{CoO})$ obtained for the recycling of spent alkaline and lithium-ion batteries. Reactions were carried out in EG at approximately $200{ }^{\circ} \mathrm{C}$ for $2 \mathrm{~h}$; in the best conditions, yields of the BHET reached $80 \%$ [126].

Functionalization of silica-coated, magnetic $\mathrm{Fe}_{3} \mathrm{O}_{4}$ nanoparticles, with an iron-containing ionic liquid, was recently employed for the glycolysis of PET to BHET. The advantage of these catalysts is in their high recyclability and ease of recovery due to their magnetic properties, and no traces of metals were found in the final products [142].

\subsubsection{Aminolysis}

While aminolysis presents the best energy and environmental parameters, the use of ammonium-based ionic liquids makes the production process more expensive $[129,143,144]$. The high temperatures involved in aminolysis are compensated for by very low depolymerization times due to increased reaction speed. Adversely, depolymerization by aminolysis of PET produces terephthalamides which have limited industrial applications. Different amines such 
as monoethanolamine (MEA) have been used for the aminolysis of PET with and without catalysts such as metal salts, quaternary ammonium compounds, and ionic liquids [145] (Scheme 5).
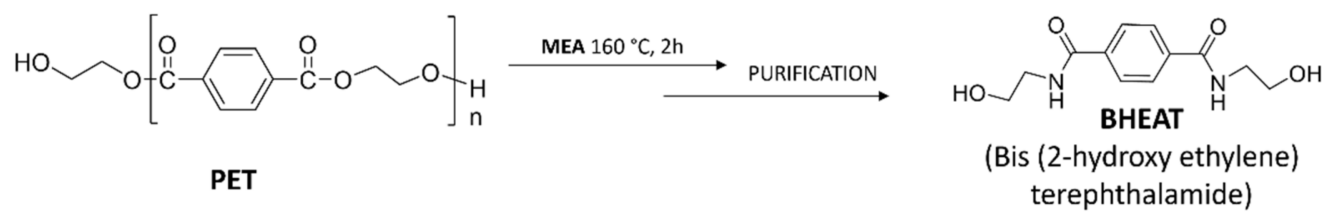

Scheme 5. PET aminolysis via monoethanolamine (MEA).

Catalyst-free, microwave-assisted aminolysis of PET proved to be an efficient method for the recovery of different terephthalamides starting from allylamine, ethanolamine, furfurylamine, or hexylamine with high selectively and yields. Terephthalamides were employed to produce good quality films [123]. Furthermore, aminolytic upcycling of PET post-consumer waste was achieved in the presence of different amino-alcohols in the presence of various organocatalysts to give diol terephthalamides, which were employed to produce poly(ester-amides) [146].

\subsection{Catalytic Depolymerization}

Plastic depolymerization may be carried out in the presence of different catalysts such as strong mineral acids, bases, organocatalysts, enzymes, and metal catalysts in homogeneous or heterogeneous phase [147].

\subsubsection{Enzymatic Catalysis}

To date, the enzymatic activity of various microbial and fungal species has been tested for the degradation of various polymers $[148,149]$. As with chemical degradation, the major difficulty in the enzyme degradation of polymers such as PE and PP derives from their high hydrophobicity, stability, and inertness, and their reactivity may be implemented by UV or thermal oxidation pretreatments [150]. While PE and PP enzymatic degradation is still a very challenging topic, numerous hydrolytic enzymes have been identified and are efficient for PET degradation [151]. PET hydrolases represent one of the most recent breakthroughs in the depolymerization of post-consumer PET, allowing the recovery of terephthalic acid and ethylene glycol at industrial relevant scale [120]. Interestingly, Sadler and coworkers developed an innovative enzyme-catalyzed post-consumer PET hydrolysis with engineered Escherichia coli to produce vanillin [134].

These new technologies once more highlight the importance of the development of specifically devised new microorganisms and enzymes for plastic depolymerization. In this connection, Santacruz Juarez and coworkers reported the use of molecular docking simulation to predict affinity, strength, and binding energy between two molecules to analyze the activity of laccase (Lac), manganese peroxidase $(\mathrm{MnP})$, lignin peroxidase $(\mathrm{LiP})$, and unspecific peroxygenase (UnP), thereby helping in the development of new enzymes [152]. Data achieved showed that synergic enzymatic combination, as it normally happens in nature, boosts the catalytic efficiency by promoting sequential degradation processes. The use of microorganisms and enzymes has been widely studied with the intent to find an environmentally sustainable solution to microplastic and nanoplastic contamination. Taghavi reviewed the state of the art of plastic packaging biodegradation by living microorganisms reporting mechanisms of action, advantages, limitations, and technology readiness levels (TRL). The focus of this very important research area is a reduction in plastic pollution in the environment more so than its recovery and reuse; thus, it is not further analyzed in this paper [148]. 


\subsubsection{Hydrogenolysis}

Hydrogenolysis is widely employed for the depolymerization of PET in the presence of hydrogen and homogeneous Milstein-type Ru-PNN complexes which are highly reactive toward the $\mathrm{C}=\mathrm{O}$ double bonds of PET to give 4-benzenedimethanol (BDM) in $99 \%$ yield at $160^{\circ} \mathrm{C}$ in $48 \mathrm{~h}$ (Table 1, entry 1), while they are ineffective in the presence of PP and PE $[147,153-155]$. More complex phosphine ligands have also been tested, but the economic viability on an industrial scale seems to be rather limited [147] (Table 1, entries 2-3).

Table 1. Phosphine ligands of Milstein-type Ru-PNN complexes.

\begin{tabular}{|c|c|c|c|c|c|c|c|c|}
\hline \multirow{2}{*}{ Entry } & \multirow{2}{*}{ Catalyst } & \multirow{2}{*}{ Co-Cat. } & \multicolumn{4}{|c|}{ Reaction Conditions } & \multirow[t]{2}{*}{$\begin{array}{c}\text { PET } \\
\text { Conv. (\%) }\end{array}$} & \multirow[t]{2}{*}{ Sel. (\%) } \\
\hline & & & $\begin{array}{c}\mathrm{T} \\
\left({ }^{\circ} \mathrm{C}\right)\end{array}$ & $\mathrm{H}_{2}$ (bar) & Solvent & $t(h)$ & & \\
\hline 1 & & $\mathrm{Kt}-\mathrm{BuO}$ & 160 & 54 & $\begin{array}{c}\text { Anisole } \\
\text { THF }\end{array}$ & 48 & 99 & $100^{1}$ \\
\hline 2 & & HNTf & 140 & 100 & Dioxane & 16 & 42 & $64^{1}$ \\
\hline 3 & & HNTf & 140 & 100 & Dioxane & 16 & 64 & $99^{1}$ \\
\hline 4 & $\mathrm{Ru} / \mathrm{Nb}_{2} \mathrm{O}_{5}$ & / & 220 & l & $\mathrm{H}_{2} \mathrm{O}$ & 12 & 91 & $100^{2}$ \\
\hline 5 & $\mathrm{Ru} / \mathrm{Nb}_{2} \mathrm{O}_{5}$ & / & 200 & 3 & $\mathrm{H}_{2} \mathrm{O}$ & 12 & 95 & $100^{2}$ \\
\hline
\end{tabular}

${ }^{1}$ Selectivity to BDM. ${ }^{2}$ Selectivity to BTX.

Two very important studies have been published on the efficient conversion of postconsumer PET to benzene, toluene, and xylenes by reportedly "unlocking hidden hydrogen in the ethylene glycol part" with $\mathrm{Ru} / \mathrm{Nb}_{2} \mathrm{O}_{5}$ catalyst $[156,157]$. The hydrogen is formed in situ during the reaction from ethylene glycol, and it appears that, in the presence of $\mathrm{Ru} / \mathrm{Nb}_{2} \mathrm{O}_{5}$, two different pathways (decarboxylation and hydrogenolysis) compete to determine the selectivity toward alkyl-aromatic compounds (Table 1, entries 4-5) [156].

Solventless hydrolysis of PET bottles to TPA and ethylene has been selectively achieved by a carbon-supported single-site molybdenum-dioxo catalyst under $260^{\circ} \mathrm{C}$ and 1 atmosphere of $\mathrm{H}_{2}$ with $87 \%$ yield. The catalyst exhibits high stability and can be recycled many times without loss of activity [158].

Hydrogenolysis of PET to liquid alkanes has been carried out under mild reaction conditions using ruthenium nanoparticles supported on carbon $(\mathrm{Ru} / \mathrm{C})$. Under optimal reaction conditions $\left(200^{\circ} \mathrm{C}, 20\right.$ bar $\mathrm{H}_{2}, 16 \mathrm{~h}$ ), PE was converted into liquid $n$-alkanes with $45 \%$ yield [159]. Another $\mathrm{SnPt} / \gamma-\mathrm{Al}_{2} \mathrm{O}_{3}$ and $\mathrm{Re}_{2} \mathrm{O}_{7} / \gamma-\mathrm{Al}_{2} \mathrm{O}_{3}$ heterogeneous catalyst was used to produce linear alkanes from HDPE. This type of catalyst promotes a tandem reaction via which poorly reactive aliphatic substrates are first activated through dehydrogenation and then functionalized or cleaved by a highly active olefin catalyst [160].

These technologies are particularly attractive from an industrial point of view as heterogeneous catalysts are generally easier to use and economically more sustainable than homogeneous ones. 


\subsubsection{Hydrosilylation}

Hydrosilylation carried out in the presence of different silanes (tetramethyldisiloxane and polymethylhydrosiloxane) and borane or Ir catalysts has also been tested in the past for the depolymerization of PET, PS, and PVC [161]. Probably because of the high cost of reagents and Ir catalysts, combined with low yields in monomers recovered, no similar studies were published in the last 12 months. An interesting alternative was proposed by Fernandes and coworkers in 2020 for the depolymerization of PET by silanes and an air-stable, cost-effective dioxomolybdenum complex, $\mathrm{MoO}_{2} \mathrm{Cl}_{2}\left(\mathrm{H}_{2} \mathrm{O}\right)_{2}$. Although reaction conditions are rather harsh $\left(160^{\circ} \mathrm{C}, 4\right.$ days), very good yields in $p$-xylene were achieved for the reductive depolymerization of PET (65\% yield) in the presence of $5 \mathrm{wt} . \%$ $\mathrm{MoO}_{2} \mathrm{Cl}_{2}\left(\mathrm{H}_{2} \mathrm{O}\right)_{2}$ and six equivalents of phenylsilane. In another study, Fernandes described the first example of reductive hydrosilylation of PET and other plastic waste using an economically and environmentally sustainable $\mathrm{Zn}$ catalyst, $\mathrm{Zn}(\mathrm{OAc})_{2} \cdot 2 \mathrm{H}_{2} \mathrm{O}$, to produce high-value-added compounds such as 1,2-propanediol, 1,6-hexanediol, tetrahydrofuran, and $p$-xylene. In the same reaction conditions, in the presence of Mo oxides, yields in $p$-xylene were equivalent while higher yields in EG were obtained (43\%) [162]. Much work surely needs to be done to implement these technologies to industrial maturity, but the use of highly available, environmentally friendly catalysts is a great advantage and should be further pursued.

\section{Thermal Recycling}

Thermal recycling mainly comprises pyrolysis, hydrocracking, and gasification (Scheme 6) [163]. Since there are no recent advancements for gasification, only pyrolysis and hydrocracking are reported. An outline of the main innovative solutions recently published is reported below.

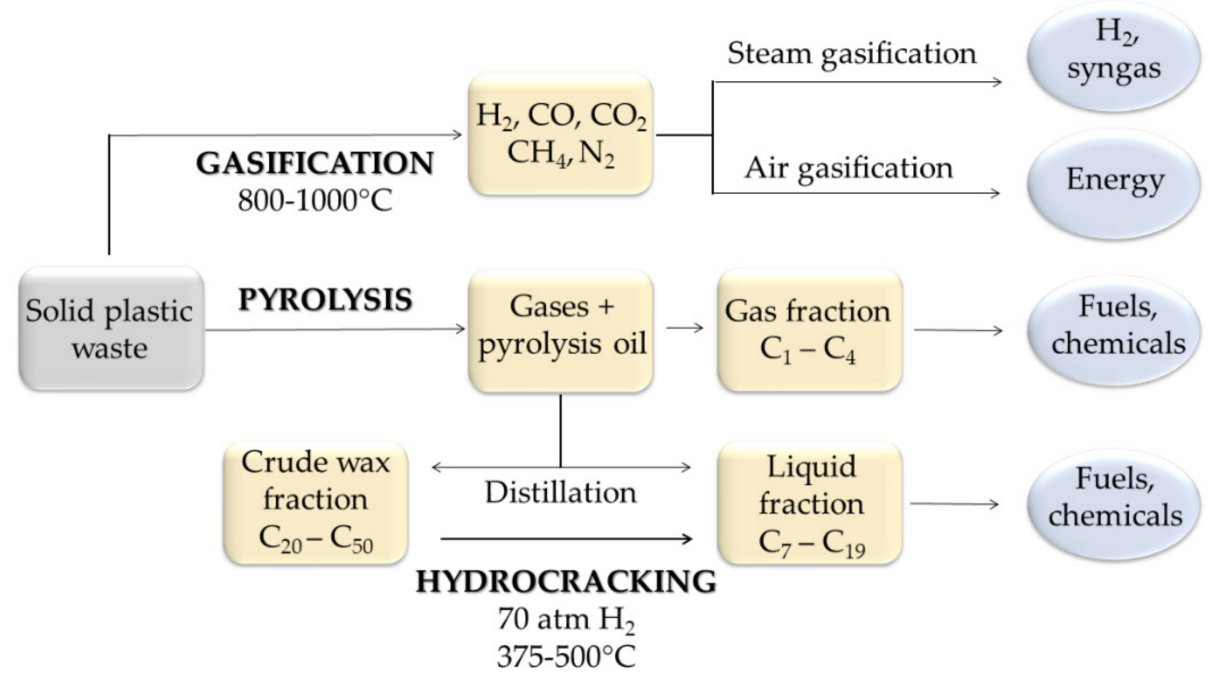

Scheme 6. General scheme of thermal recycling processes.

\subsection{Pyrolysis}

Pyrolysis, or thermal cracking, is a process that occurs at high temperatures $\left(500{ }^{\circ} \mathrm{C}\right)$ and in the absence of oxygen. Different kinds of catalysts can be used to improve the efficiency of the pyrolysis process since they target a specific reaction and reduce the process temperature and time [164]. Unlike other thermochemical conversion methods, pyrolysis leads to liquid or wax mixtures rich in hydrocarbons, an ideal raw material for a refinery [165]. Thermal pyrolysis is typically used for the recycling of those polymers for which depolymerization is harsh and that are not currently mechanically recyclable (PE/PP/PS mixtures, multilayer packaging, and reinforced fibers). Thanks to the high temperatures, it guarantees molecular bond breaking in the polymer chains to give, depending on the nature of the polymer, depolymerization or random fragmentation [122,166]. Alternatively, 
catalytic pyrolysis can be performed on the same polymers at lower temperatures by carbocation formation and subsequent isomerization [161]. Both thermal and catalytic pyrolysis approaches are not selective, but advantages rely on high conversions, thermal stability of the products and, in some cases, high-value enriched oil production. Pyrolysis, therefore, is an interesting recycling approach for a safe circular economy $[161,166]$.

Pyrolysis must be preceded by pretreatment of the plastic waste, to ensure that it is not contaminated by non-plastic materials such as metal and wood. This step is necessary to ensure the economic feasibility of the plastic-to-fuel (PTF) plant, and it can usually be achieved by sorting, crushing, or sieving depending on the origin of the waste. Since pretreatment techniques are consolidated methodologies, no innovative methods were reported in the last year.

Another important aspect derives from different sources of plastic processed which may be different in shape and size, requiring to be uniformly sized as grains before feeding into the pyrolysis process. This step adds an extra cost to the process.

Depending on the type of reactor, the pre-sizing step can be skipped or modified. For example, rotary kilns can accommodate differently sized and shaped plastics; hence, the pre-sizing step can be avoided. Fluidized bed reactors, instead, need to have uniform thermodynamics in the reactor; therefore, plastic waste should be evenly sized. To cope with this challenge, several feeding devices have been tested [166].

Currently, the study of catalytic pyrolysis is very active, and a wide range of synthetic catalysts have been employed to enhance the overall pyrolysis process and to improve the quality of produced liquid oil.

Most PE pyrolysis approaches are promoted by heterogeneous acid catalysts (e.g., zeolites, alumina, and silica) and are usually unselective, resulting in a broad distribution of gas (C3 and C4 hydrocarbons), liquid (cycloparaffins, oligomers, and aromatics), and solid products (char, coke). This behavior is due to the radical mechanism of the $\mathrm{C}-\mathrm{C}$ bond scission, leading to a complex mixture of olefinic and cross-linked compound $[122,166]$.

A very recent novel study on this topic was carried out by Miandad and coworkers, in which the effect on yield and product quality of Saudi natural zeolite was investigated [164]. Saudi natural zeolite catalyst was improved via novel thermal activation (TA-NZ) at $550{ }^{\circ} \mathrm{C}$ and acid activation (AA-NZ) with $\mathrm{HNO}_{3}$. Pyrolysis feedstock was composed of single or mixed PS, PE, PP, and PET, in the presence of both modified natural zeolite (NZ) catalysts. The authors reported that PS produced the highest yield in liquid oil, i.e., $70 \%$ and $60 \%$ using the TA-NZ and AA-NZ catalysts, respectively, compared to PP (40\% and $54 \%)$ and PE (40\% and $42 \%)$.

In addition to zeolite, the research on catalytic pyrolysis has focused on other catalytic systems, always considering that the catalytic activity of the catalyst is derived from its Lewis acid sites. Most homogeneous catalysts for polyolefin degradation have been classical Lewis acids such as $\mathrm{AlCl}_{3}$. On the basis of these considerations, Su and coworkers [167] worked on $\mathrm{AlCl}_{3}-\mathrm{NaCl}$ eutectic salt as a catalyst, allowing a reduction in reaction temperature, an increase in reaction rate, a reduction in heavy oil components, and the inhibition of polyolefin formation.

Pyrolysis is most often adopted to convert plastic waste to fuels. An example of differentiation is the production of high-value-added carbon nanotubes (CNTs) [168] using a metallic Ni catalyst supported on different oxides and generated in situ. Selectivity, yield, and structural properties were tuned according to the degree of metal-support interaction in different catalysts.

\subsection{Hydrocracking}

Hydrocracking is a catalytic refining process for the selective recovery of useful chemical fractions in the range of heavy diesel to light naphtha. Hydrocracking requires a bifunctional catalyst with an acidic function, enhancing the cracking activity, typically provided by a high-surface-area support, such as a zeolite [169]. 
Recent studies have focused on the conversion of both post-consumer and laboratory polymers in mild conditions, using a metal-zeolite catalytic system.

Jumah and coworkers [170] treated low- and high-density polyethylene (LDPE, HDPE), polypropylene (PP), and polystyrene (PS) to produce liquid petrol gas (C3-C4) and naphtha. They reported the effect of both the catalyst morphology (beta zeolite impregnated with $1 \% \mathrm{Pt}$ ) and the feed stream variation, by reacting different polymers individually and post-consumer polymer mixtures.

Another recent work described the transformation of PE, PP, and PS into methane ( $>97 \%$ purity) at $300-350{ }^{\circ} \mathrm{C}$ using near-stoichiometric amounts of $\mathrm{H}_{2}$ in the presence of a Ru-modified zeolite as a catalyst [171].

\section{Conclusions}

Ideally, the route to achieve a sustainable society is to replace synthetic plastics. A plastic-free world, however, is presently utopistic, and great effort must be applied in the pursuit of a drastic change in end-of-life plastic waste treatment and management.

In this review, we presented a highlight of the very latest technologies being developed to enhance the recycling efficiency of polymers and to generate high-value products from plastic waste.

Mechanical recycling and chemical upcycling appear to be the most promising strategies, since incineration and landfill are more pollutant and, for the latter, plastic waste completely loses its value.

Although, in the last few years, researchers have focused on chemical treatments, mechanical recycling is still the more mature and better performing technique. The lack of adequate infrastructures and technologies is limiting the industrialization of chemical upcycling, as well as the replacement of current materials with more sustainable polymers.

Future solutions will mainly focus on the development of biodegradable materials, completely recyclable polymers, and depolymerization/repolymerization pathways that allow to maximize the plastic life cycle.

Waste is a very serious problem and is intimately related to environmental and socialeconomic impacts. The problem of waste must be considered holistically from governments, industries, and stakeholders to preserve human health and guarantee the world survival. A deep change in mentalities at all levels is necessary to approach the impact of humanity and the industry on the environment; therefore, a high level of information is required to achieve awareness and promote sustainable processes and products. Too much information is available today; thus, that the scientific community must help give clear and well-justified indications regarding the best technologies to be adopted in the future. The authors hope that this mini-review will contribute to this consciousness and positively impact future choices.

Author Contributions: Conceptualization, V.B.; writing—original draft preparation, V.B., M.F., R.S., C.B. and M.A.-A.; writing-review and editing, V.B., M.F., R.S., C.B. and M.A.-A.; supervision, V.B. All authors read and agreed to the published version of the manuscript.

Funding: This research was funded by POR FESR Veneto 2014-2020 Asse 1. Azione 1.1.4 (project title: Advanced waste recovery systems-ID 10057503).

Institutional Review Board Statement: Not applicable.

Informed Consent Statement: Not applicable.

Data Availability Statement: Not applicable.

Conflicts of Interest: The authors declare no conflict of interest. 


\section{References}

1. Leal Filho, W.; Saari, U.; Fedoruk, M.; Iital, A.; Moora, H.; Klöga, M.; Voronova, V. An overview of the problems posed by plastic products and the role of extended producer responsibility in europe. J. Clean. Prod. 2019, 214, 550-558. [CrossRef]

2. Rasmussen, S.C. From parkesine to celluloid: The birth of organic plastics. Angew. Chem. Int. Ed. 2021, 60, 8012-8016. [CrossRef] [PubMed]

3. Chalmin, P. The history of plastics: From the capitol to the tarpeian rock. FACTS 2019, 19, 6-11.

4. Geyer, R.; Jambeck, J.R.; Law, K.L. Production, use, and fate of all plastics ever made. Sci. Adv. 2017, 3, 1-5. [CrossRef] [PubMed]

5. Gilbert, M. Plastics materials: Introduction and historical development. In Brydson's Plastics Materials, 8th ed.; Elsevier Inc.: Amsterdam, The Netherlands, 2016; pp. 2-18. [CrossRef]

6. Scalenghe, R. Resource or waste? A perspective of plastics degradation in soil with a focus on end-of-life options. Heliyon 2018, 4, 1-39. [CrossRef]

7. Paletta, A.; Leal Filho, W.; Balogun, A.L.; Foschi, E.; Bonoli, A. Barriers and challenges to plastics valorisation in the context of a circular economy: Case studies from italy. J. Clean. Prod. 2019, 241, 118149-118164. [CrossRef]

8. Foschi, E.; Bonoli, A. The commitment of packaging industry in the framework of the european strategy for plastics in a circular economy. Adm. Sci. 2019, 9, 18. [CrossRef]

9. Plastics Europe. Plastics-The Facts 2020 an Analysis of European Plastics Production, Demand and Waste Data; Plastics Europe: Brussels, Belgium, 2020.

10. Ahmed, T.; Shahid, M.; Azeem, F.; Rasul, I.; Shah, A.A.; Noman, M.; Hameed, A.; Manzoor, N.; Manzoor, I.; Muhammad, S. Biodegradation of plastics: Current scenario and future prospects for environmental safety. Environ. Sci. Pollut. Res. 2018, 25, 7287-7298. [CrossRef]

11. Gatto, V.; Conca, S.; Bardella, N.; Beghetto, V. Efficient triazine derivatives for collagenous materials stabilization. Materials 2021, 14, 3069. [CrossRef]

12. Asgher, M.; Qamar, S.A.; Bilal, M.; Iqbal, H.M.N. Bio-based active food packaging materials: Sustainable alternative to conventional petrochemical-based packaging materials. Int. Food Res. J. 2020, 137, 109625-109637. [CrossRef]

13. Mochane, M.J.; Magagula, S.I.; Sefadi, J.S.; Mokhena, T.C. A review on green composites based on natural fiber-reinforced polybutylene succinate (PBS). Polymers 2021, 13, 1200. [CrossRef] [PubMed]

14. Rafiqah, S.A.; Khalina, A.; Harmaen, A.S.; Tawakkal, I.A.; Zaman, K.; Asim, M.; Nurrazi, M.N.; Lee, C.H. A review on properties and application of bio-based poly(butylene succinate). Polymers 2021, 13, 1436. [CrossRef] [PubMed]

15. Saratale, R.G.; Cho, S.K.; Saratale, G.D.; Kadam, A.A.; Ghodake, G.S.; Kumar, M.; Bharagava, R.N.; Kumar, G.; Kim, D.S.; Mulla, S.I.; et al. A Comprehensive overview and recent advances on polyhydroxyalkanoates (pha) production using various organic waste streams. Bioresour. Technol. 2021, 325, 124685-124700. [CrossRef] [PubMed]

16. De Donno Novelli, L.; Moreno Sayavedra, S.; Rene, E.R. Polyhydroxyalkanoate (PHA) production via resource recovery from industrial waste streams: A review of techniques and perspectives. Bioresour. Technol. 2021, 331, 124895-124908. [CrossRef] [PubMed]

17. Al Battashi, H.; Al-Kindi, S.; Gupta, V.K.; Sivakumar, N. Polyhydroxyalkanoate (PHA) production using volatile fatty acids derived from the anaerobic digestion of waste paper. J. Polym. Environ. 2021, 29, 250-259. [CrossRef]

18. Rosenboom, J.G.; Hohl, D.K.; Fleckenstein, P.; Storti, G.; Morbidelli, M. Bottle-Grade polyethylene furanoate from ring-opening polymerisation of cyclic oligomers. Nat. Commun. 2018, 9, 1-7. [CrossRef] [PubMed]

19. Al Ghatta, A.; Wilton-Ely, J.D.E.T.; Hallett, J.P. From sugars to fdca: A techno-economic assessment using a design concept based on solvent selection and carbon dioxide emissions. Green Chem. 2021, 23, 1716-1733. [CrossRef]

20. Filiciotto, L.; Rothenberg, G. Biodegradable plastics: Standards, policies, and impacts. ChemSusChem 2021, 14, 56-72. [CrossRef]

21. Ojogbo, E.; Ogunsona, E.O.; Mekonnen, T.H. Chemical and physical modifications of starch for renewable polymeric materials. Mater. Today Sustain. 2020, 7, 1-25. [CrossRef]

22. De Freitas, A.d.S.M.; Rodrigues, J.S.; Maciel, C.C.; Pires, A.A.F.; Lemes, A.P.; Ferreira, M.; Botaro, V.R. Improvements in thermal and mechanical properties of composites based on thermoplastic starch and kraft lignin. Int. J. Biol. Macromol. 2021, 184, 863-873. [CrossRef]

23. Cecone, C.; Costamagna, G.; Ginepro, M.; Trotta, F. One-Step sustainable synthesis of cationic high-swelling polymers obtained from starch-derived maltodextrins. RSC Adv. 2021, 11, 7653-7662. [CrossRef]

24. Zarski, A.; Bajer, K.; Kapuśniak, J. Review of the most important methods of improving the processing properties of starch toward non-food applications. Polymers 2021, 13, 832. [CrossRef]

25. Beghetto, V.; Gatto, V.; Conca, S.; Bardella, N.; Buranello, C.; Gasparetto, G.; Sole, R. Development of 4-(4,6-dimethoxy-1,3,5triazin-2-yl)-4-methyl-morpholinium chloride cross-linked carboxymethyl cellulose films. Carbohydr. Polym. 2020, $249,1-11$. [CrossRef] [PubMed]

26. Khezerlou, A.; Zolfaghari, H.; Banihashemi, S.A.; Forghani, S.; Ehsani, A. Plant gums as the functional compounds for edible films and coatings in the food industry: A review. Carbohydr. Polym. 2021, 32, 2306-2326. [CrossRef]

27. Fu, Y.; Dudley, E.G. Antimicrobial-coated films as food packaging: A review. Compr. Rev. Food Sci. Food Saf. 2021, 20, 3404-3437. [CrossRef] [PubMed]

28. Hashmi, M.; Ullah, S.; Ullah, A.; Saito, Y.; Haider, M.K.; Bie, X.; Wada, K.; Kim, I.S. Carboxymethyl cellulose (cmc) based electrospun composite nanofiber mats for food packaging. Polymers 2021, 13, 302. [CrossRef] 
29. Panahirad, S.; Dadpour, M.; Peighambardoust, S.H.; Soltanzadeh, M.; Gullón, B.; Alirezalu, K.; Lorenzo, J.M. applications of carboxymethyl cellulose- and pectin-based active edible coatings in preservation of fruits and vegetables: A review. Trends Food Sci. Technol. 2021, 110, 663-673. [CrossRef]

30. Beghetto, V.; Gatto, V.; Conca, S.; Bardella, N.; Scrivanti, A. Polyamidoamide dendrimers and cross-linking agents for stabilized bioenzymatic resistant metal-free bovine collagen. Molecules 2019, 24, 3611. [CrossRef]

31. Luzi, F.; Torre, L.; Kenny, J.M.; Puglia, D. Bio- and fossil-based polymeric blends and nanocomposites for packaging: Structureproperty relationship. Materials 2019, 12, 471. [CrossRef]

32. Papadopoulos, A.N. Advances in wood composites III. Polymers 2021, 13, 163. [CrossRef] [PubMed]

33. Wasti, S.; Triggs, E.; Farag, R.; Auad, M.; Adhikari, S.; Bajwa, D.; Li, M.; Ragauskas, A.J. Influence of plasticizers on thermal and mechanical properties of biocomposite filaments made from lignin and polylactic acid for $3 \mathrm{~d}$ printing. Compos. Part B Eng. 2021, 205-213. [CrossRef]

34. Cavallo, E.; He, X.; Luzi, F.; Dominici, F.; Cerrutti, P.; Bernal, C.; Foresti, M.L.; Torre, L.; Puglia, D. UV Protective, antioxidant, antibacterial and compostable polylactic acid composites containing pristine and chemically modified lignin nanoparticles. Molecules 2020, 26, 126. [CrossRef] [PubMed]

35. Sole, R.; Taddei, L.; Franceschi, C.; Beghetto, V. Efficient chemo-enzymatic transformation of animal biomass waste for ecofriendly leather production. Molecules 2019, 24, 2979. [CrossRef]

36. Chandra Dubey, S.; Mishra, V.; Sharma, A. A review on polymer composite with waste material as reinforcement. Mater. Today Proc. 2021, in press. [CrossRef]

37. Sid, S.; Mor, R.S.; Kishore, A.; Sharanagat, V.S. Bio-sourced polymers as alternatives to conventional food packaging materials: A review. Trends Food Sci. Technol. 2021, 115, 87-104. [CrossRef]

38. European Bioplastics. European Bioplastic Report 2019 2020_Bioplastics Market Data 2019, Global Production Capacities of Bioplastics 2019-2024; Market Report; European Bioplastics: Berlin, Germany, 2020.

39. Mendes, A.C.; Pedersen, G.A. Perspectives on sustainable food packaging: Is bio-based plastics a solution? Trends Food Sci. Technol. 2021, 112, 839-846. [CrossRef]

40. Streit-Bianchi, M.; Cimadevila, M.; Trettnak, W. Mare Plasticum-The Plastic Sea Combatting Plastic Pollution through Science and Art, 1st ed.; Springer: Berlin, Germany, 2020; pp. 250-252.

41. Kabir, A.H.M.E.; Sekine, M.; Imai, T.; Yamamoto, K.; Kanno, A.; Higuchi, T. Assessing small-scale freshwater microplastics pollution, land-use, source-to-sink conduits, and pollution risks: Perspectives from japanese rivers polluted with microplastics. Sci. Total Environ. 2021, 768-781. [CrossRef]

42. Woodward, J.; Li, J.; Rothwell, J.; Hurley, R. Acute riverine microplastic contamination due to avoidable releases of untreated wastewater. Nat. Sustain. 2021, 1-10. [CrossRef]

43. Akanyange, S.N.; Lyu, X.; Zhao, X.; Li, X.; Zhang, Y.; Crittenden, J.C.; Anning, C.; Chen, T.; Jiang, T.; Zhao, H. Does microplastic really represent a threat? a review of the atmospheric contamination sources and potential impacts. Sci. Total Environ. 2021, 777, 146020. [CrossRef]

44. Garcia, A.G.; Suárez, D.C.; Li, J.; Rotchell, J.M. A Comparison of microplastic contamination in freshwater fish from natural and farmed sources. Environ. Sci. Pollut. R. 2021, 28, 14488-14497. [CrossRef]

45. Zhou, Y.; He, G.; Jiang, X.; Yao, L.; Ouyang, L.; Liu, X.; Liu, W.; Liu, Y. Microplastic contamination is ubiquitous in riparian soils and strongly related to elevation, precipitation and population density. J. Hazard. Mater. 2021, 411, 125178-125191. [CrossRef]

46. Jambeck, J.R.; Geyer, R.; Wilcox, C.; Siegler, T.R.; Perryman, M.; Andrady, A.; Narayan, R.; Law, K.L. Plastic waste inputs from land into the ocean. Science 2015, 347, 768-771. [CrossRef] [PubMed]

47. Mai, L.; He, H.; Bao, L.J.; Liu, L.Y.; Zeng, E.Y. Plastics are an insignificant carrier of riverine organic pollutants to the coastal oceans. Environ. Sci. Technol. 2020, 54, 15852-15860. [CrossRef] [PubMed]

48. De Sousa, F.D.B. The role of plastic concerning the sustainable development goals: The literature point of view. Clean. Respons. Consump. 2021, 3, 100020-100044. [CrossRef]

49. Sitadewi, D.; Yudoko, G.; Okdinawati, L. Bibliographic mapping of post-consumer plastic waste based on hierarchical circular principles across the system perspective. Heliyon 2021, 7, 1-23. [CrossRef] [PubMed]

50. Mantalovas, K.; di Mino, G. Integrating circularity in the sustainability assessment of asphalt mixtures. Sustainability 2020, $12,594$. [CrossRef]

51. Ellen Mac Arthur Foundation. The Global Commitment 2020 Progress Report; Technical Report; Ellen Mac Arthur Foundation: Cowes, UK, 2020.

52. Jain, R.; Tiwari, A. Biosynthesis of planet friendly bioplastics using renewable carbon source. J. Environ. Health Sci. Eng. 2015, 13, 1-5. [CrossRef]

53. Landi, D.; Cicconi, P.; Germani, M. Analyzing the environmental sustainability of packaging for household appliances: A test case. In Proceedings of the Procedia CIRP; Elsevier B.V.: Amsterdam, The Netherlands, 2020; Volume 90, pp. 355-360.

54. Rigamonti, L.; Grosso, M.; Møller, J.; Martinez Sanchez, V.; Magnani, S.; Christensen, T.H. Environmental evaluation of plastic waste management scenarios. Resour. Conserv. Recy. 2014, 85, 42-53. [CrossRef]

55. Tang, Y.; Liu, Y.; Chen, Y.; Zhang, W.; Zhao, J.; He, S.; Yang, C.; Zhang, T.; Tang, C.; Zhang, C.; et al. A review: Research progress on microplastic pollutants in aquatic environments. Sci. Total Environ. 2021, 766, 142572-142587. [CrossRef] 
56. Liang, Y.; Tan, Q.; Song, Q.; Li, J. An analysis of the plastic waste trade and management in Asia. Waste Manag. 2021, 119, $242-253$. [CrossRef]

57. Basuhi, R.; Moore, E.; Gregory, J.; Kirchain, R.; Gesing, A.; Olivetti, E.A. Environmental and economic implications of u.s. postconsumer plastic waste management. Resour. Conserv. Recy. 2021, 167, 1-11. [CrossRef]

58. Brouwer, M.T.; Thoden van Velzen, E.U.; Augustinus, A.; Soethoudt, H.; de Meester, S.; Ragaert, K. Predictive model for the dutch post-consumer plastic packaging recycling system and implications for the circular economy. Waste Manag. 2018, 71, 62-85. [CrossRef] [PubMed]

59. Hsu, W.-T.; Domenech, T.; McDowall, W. How circular are plastics in the EU?: MFA of plastics in the eu and pathways to circularity. J. Clean. Prod. 2021, 2, 100004-100013. [CrossRef]

60. Van Eygen, E.; Laner, D.; Fellner, J. Circular economy of plastic packaging: Current practice and perspectives in austria. Waste Manag. 2018, 72, 55-64. [CrossRef]

61. Balwada, J.; Samaiya, S.; Mishra, R.P. Packaging Plastic Waste Manage, for a Circular Economy and Identifying a Better Waste Collection System Using Analytical Hierarchy Process (AHP). In Proceedings of the Procedia CIRP; Elsevier B.V.: Amsterdam, The Netherlands, 2021; Volume 98, pp. 270-275. [CrossRef]

62. Ragossnig, A.M.; Agamuthu, P. Plastic waste: Challenges and opportunities. Waste Manag. Res. 2021, 39, 629-630. [CrossRef]

63. Larrain, M.; van Passel, S.; Thomassen, G.; van Gorp, B.; Nhu, T.T.; Huysveld, S.; van Geem, K.M.; de Meester, S.; Billen, P. Techno-economic assessment of mechanical recycling of challenging post-consumer plastic packaging waste. Resour. Conserv. Recy. 2021, 170, 105607-105620. [CrossRef]

64. Lombardi, M.; Rana, R.; Fellner, J. Material flow analysis and sustainability of the italian plastic packaging management. J. Clean. Prod. 2021, 287, 125573-125581. [CrossRef]

65. Bishop, G.; Styles, D.; Lens, P.N.L. Recycling of european plastic is a pathway for plastic debris in the ocean. Environ. Int. 2020, 142, 105893-105905. [CrossRef]

66. Lebreton, L.; Andrady, A. Future scenarios of global plastic waste generation and disposal. Palgrave Commun. 2019, 5, 1-10. [CrossRef]

67. Da Costa, J.P.; Mouneyrac, C.; Costa, M.; Duarte, A.C.; Rocha-Santos, T. The role of legislation, regulatory initiatives and guidelines on the control of plastic pollution. Front. Environ. Sci. 2020, 8, 1-14. [CrossRef]

68. European Commission. A European Strategy for Plastics in a Circular Economy. In Communication from the Commission to the European Parliament; The Council, The European Economic and Social Committee and The Committee af The Regions: Brussels, Belgium, 2018.

69. Mah, A. Future-Proofing Capitalism: The Paradox of the Circular Economy for Plastics. Glob. Environ. Politics 2021, 21, 121-142. [CrossRef]

70. Payne, J.; Jones, M.D. The chemical recycling of polyesters for a circular plastics economy: Callenges and emerging opportunities. ChemSusChem 2021, 14, 1-31. [CrossRef]

71. Gundupalli, S.P.; Hait, S.; Thakur, A. A review on automated sorting of source-separated municipal solid waste for recycling. Waste Manag. 2017, 60, 56-74. [CrossRef] [PubMed]

72. Schwarz, A.E.; Ligthart, T.N.; Godoi Bizarro, D.; de Wild, P.; Vreugdenhil, B.; van Harmelen, T. Plastic recycling in a circular economy; determining environmental performance through an lca matrix model approach. Waste Manag. 2021, 121, $331-342$. [CrossRef] [PubMed]

73. Idumah, C.I.; Nwuzor, I.C. Novel trends in plastic waste management. SN Appl. Sci. 2019, 1, 1402-1416. [CrossRef]

74. Shen, L.; Worrell, E. Plastic recycling. In Handbook of Recycling: State-of-the-Art for Practitioners, Analysts, and Scientists; Elsevier Inc.: Amsterdam, The Netherlands, 2014; pp. 179-190.

75. Briassoulis, D.; Pikasi, A.; Hiskakis, M. Recirculation potential of post-consumer /industrial bio-based plastics through mechanical recycling-Techno-economic sustainability criteria and indicators. Polym. Degrad. Stab. 2021, 183, 109217-109237. [CrossRef]

76. Bening, C.R.; Pruess, J.T.; Blum, N.U. Towards a circular plastics economy: Interacting barriers and contested solutions for flexible packaging recycling. J. Clean. Prod. 2021, 302, 126966-126985. [CrossRef]

77. Kumar, R. Tertiary and Quaternary Recycling of Thermoplastics by Additive Manufacturing Approach for Thermal Sustainability. Mater. Today Proc. 2020, 37, 2382-2386. [CrossRef]

78. Gopinath, K.P.; Nagarajan, V.M.; Krishnan, A.; Malolan, R. A critical review on the influence of energy, environmental and economic factors on various processes used to handle and recycle plastic wastes: Development of a comprehensive index. J. Clean. Prod. 2020, 274, 123031-123047. [CrossRef]

79. Davidson, M.G.; Furlong, R.A.; McManus, M.C. Developments in the life cycle assessment of chemical recycling of plastic waste-A review. J. Clean. Prod. 2021, 293, 126163-126175. [CrossRef]

80. Thiounn, T.; Smith, R.C. Advances and approaches for chemical recycling of plastic waste. J. Polym. Sci. 2020, 58, 1347-1364. [CrossRef]

81. Antonopoulos, I.; Faraca, G.; Tonini, D. Recycling of post-consumer plastic packaging waste in eu: Process efficiencies, material flows, and barriers. Waste Manag. 2021, 126, 694-705. [CrossRef]

82. Ncube, L.K.; Ude, A.U.; Ogunmuyiwa, E.N.; Zulkifli, R.; Beas, I.N. An overview of plastic waste generation and management in food packaging industries. Recycling 2021, 6, 12. [CrossRef] 
83. Chen, X.; Wang, Y.; Zhang, L. Recent progress in the chemical upcycling of plastic wastes. ChemSusChem 2021, 14, 1-16. [CrossRef]

84. Chen, H.; Wan, K.; Zhang, Y.; Wang, Y. Waste to wealth: Chemical recycling and chemical upcycling of waste plastics for a great future. ChemSusChem 2021, 14, 1-15. [CrossRef]

85. Schyns, Z.O.G.; Shaver, M.P. Mechanical recycling of packaging plastics: A review. Macromol. Rapid Commun. 2021, $42,2000415$. [CrossRef] [PubMed]

86. Mulakkal, M.C.; Castillo Castillo, A.; Taylor, A.C.; Blackman, B.R.K.; Balint, D.S.; Pimenta, S.; Charalambides, M.N. Advancing mechanical recycling of multilayer plastics through finite element modelling and environmental policy. Resour. Conserv. Recy. 2021, 166, 105371. [CrossRef]

87. Ellen Mac Arthur Foundation. The New Plastics Economy: Rethinking the Future of Plastics E Catalysing Action; Ellen Mac Arthur Foundation: Cowes, UK, 2016.

88. Lange, J.-P. Towards circular carbo-chemicals-the metamorphosis of petrochemicals. Energy Environ. Sci. 2021, 14, 4358-4376. [CrossRef]

89. Rahimi, A.R.; Garciá, J.M. Chemical recycling of waste plastics for new materials production. Nat. Rev. Chem. 2017, 1-11. [CrossRef]

90. Serranti, S.; Bonifazi, G. Techniques for separation of plastic wastes. In Use of Recycled Plastics in Eco-efficient Concrete; Elsevier: Amsterdam, The Netherlands, 2019; pp. 9-37. [CrossRef]

91. Das, S.K.; Eshkalak, S.K.; Chinnappan, A.; Ghosh, R.; Jayathilaka, W.A.D.M.; Baskar, C.; Ramakrishna, S. Plastic recycling of polyethylene terephthalate (PET) and polyhydroxybutyrate (PHB)—A comprehensive review. Mater. Circ. Econ. 2021, 3, 1-22. [CrossRef]

92. Na, H.; Yoo, K.; Jha, M.K.; Tabelin, C.B. The separation of aluminum and stainless-steel scraps using vibrating mixed-size ball bed. Metals 2020, 10, 868. [CrossRef]

93. Selina, M.; Markus, B.; Daniel, S.; Renato, S. Wet-mechanical processing of a plastic-rich two-dimensional-fraction from mixed wastes for chemical recycling. Waste Manag. Res. 2021, 39, 731-743. [CrossRef]

94. Schwabl, D.; Bauer, M.; Lehner, M. Advancing plastic recycling by wet-mechanical processing of mixed waste fractions. Processes 2021, 9, 493. [CrossRef]

95. Civancik-Uslu, D.; Nhu, T.T.; van Gorp, B.; Kresovic, U.; Larrain, M.; Billen, P.; Ragaert, K.; de Meester, S.; Dewulf, J.; Huysveld, S. Moving from Linear to Circular Household Plastic packaging in belgium: Prospective life cycle assessment of mechanical and thermochemical recycling. Resour. Conserv. Recy. 2021, 171, 105633. [CrossRef]

96. Zhang, Y.; Jiang, H.; Du, Y.; Wang, C.; Wang, H. Surface alcoholysis induced by alkali-activation ethanol: A novel scheme for binary flotation of polyethylene terephthalate from other plastics. J. Clean. Prod. 2021, 314, 128096. [CrossRef]

97. Heidarpour, M.; Movahed, S.O.; Jourabchi, S. The effect of microwave irradiation on the flotation of the selected polymers as a potential solution for plastic recycling. J. Polym. Environ. 2021, 1-15. [CrossRef]

98. Tanısal1, E.; Özer, M.; Burat, F. Precious metals recovery from waste printed circuit boards by gravity separation and leaching. Min. Proc. Extr. Met. Rev. 2020, 24-37. [CrossRef]

99. Bilesan, M.R.; Makarova, I.; Wickman, B.; Repo, E. Efficient separation of precious metals from computer waste printed circuit boards by hydrocyclone and dilution-gravity methods. J. Clean. Prod. 2021, 286, 125505. [CrossRef]

100. Huang, Z.; Zhu, J.; Wu, X.; Qiu, R.; Xu, Z.; Ruan, J. Eddy current separation can be used in separation of non-ferrous particles from crushed waste printed circuit boards. J. Clean. Prod. 2021, 312, 127755. [CrossRef]

101. Nie, C.C.; Shi, S.X.; Lyu, X.J.; Wu, P.; Wang, J.X.; Zhu, X. Settlement behavior and stratification of waste printed circuit boards particles in gravitational field. Resour. Conserv. Recy. 2021, 170, 105615. [CrossRef]

102. Araujo-Andrade, C.; Bugnicourt, E.; Philippet, L.; Rodriguez-Turienzo, L.; Nettleton, D.; Hoffmann, L.; Schlummer, M. Review on the photonic techniques suitable for automatic monitoring of the composition of multi-materials wastes in view of their posterior recycling. Waste Manag. Res. 2021, 39, 631-651. [CrossRef] [PubMed]

103. Duan, Q.; Li, J. Classification of common household plastic wastes combining multiple methods based on near-infrared spectroscopy. ACS ESET Eng. 2021, 7, 1065-1073. [CrossRef]

104. Thoden van Velzen, E.U.; Chu, S.; Alvarado Chacon, F.; Brouwer, M.T.; Molenveld, K. The impact of impurities on the mechanical properties of recycled polyethylene. Packag. Technol. Sci. 2021, 34, 219-228. [CrossRef]

105. Cacciari, I.; Corradi, G. Common plastics THz classification via artificial neural networks: A discussion on a class of time domain features. Opt. Mater. 2021, 117, 111134. [CrossRef]

106. Zeng, Q.; Sirven, J.B.; Gabriel, J.C.P.; Tay, C.Y.; Lee, J.M. Laser induced breakdown spectroscopy for plastic analysis. Trac-Trend. Anal. Chem. 2021, 140, 16280. [CrossRef]

107. Bobulski, J.; Kubanek, M. Deep learning for plastic waste classification system. Appl. Comput. Intell. Soft Comput. 2021, 1, 3-4. [CrossRef]

108. Knappich, F.; Klotz, M.; Schlummer, M.; Wölling, J.; Mäurer, A. Recycling process for carbon fiber reinforced plastics with polyamide 6, polyurethane and epoxy matrix by gentle solvent treatment. Waste Manag. 2019, 85, 73-81. [CrossRef]

109. Georgiopoulou, I.; Pappa, G.D.; Vouyiouka, S.N.; Magoulas, K. Recycling of post-consumer multilayer tetra pak®packaging with the selective dissolution-precipitation process. Resouer. Conserv. Recy. 2021, 165, 105268. [CrossRef]

110. Sherwood, J. Closed-Loop Recycling of Polymers Using Solvents. Johns. Matthey Technol. Rev. 2020, 64, 4-15. [CrossRef] 
111. Vollmer, I.; Jenks, M.J.F.; Roelands, M.C.P.; White, R.J.; van Harmelen, T.; de Wild, P.; van der Laan, G.P.; Meirer, F.; Keurentjes, J.T.F.; Weckhuysen, B.M. Beyond mechanical recycling: Giving new life to plastic waste. Angew. Chem. Int. Ed. 2020, 59, 15402-15423. [CrossRef]

112. Wang, S.; Ma, S.; Qiu, J.; Tian, A.; Li, Q.; Xu, X.; Wang, B.; Lu, N.; Liu, Y.; Zhu, J. Upcycling of post-consumer polyolefin plastics to covalent adaptable networksvia in situcontinuous extrusion cross-linking. Green Chem. 2021, 23, 2931-2937. [CrossRef]

113. Roosen, M.; Mys, N.; Kusenberg, M.; Billen, P.; Dumoulin, A.; Dewulf, J.; van Geem, K.M.; Ragaert, K.; De Meester, S. Detailed analysis of the composition of selected plastic packaging waste products and its implications for mechanical and thermochemical recycling. Environ. Sci. Technol. 2020, 54, 13282-13293. [CrossRef]

114. Eriksen, M.K.; Christiansen, J.D.; Daugaard, A.E.; Astrup, T.F. Closing the loop for pet, pe and pp waste from households: Influence of material properties and product design for plastic recycling. J. Waste Manag. 2019, 96, 75-85. [CrossRef] [PubMed]

115. Korley, L.T.J.; Epps, T.H.; Helms, B.A.; Ryan, A.J. Toward polymer upcycling-adding value and tackling circularity. Science 2021, 373, 66-69. [CrossRef] [PubMed]

116. Chanda, M. Chemical aspects of polymer recycling. Adv. Ind. Eng. Polym. Res. 2021, 4, 133-150. [CrossRef]

117. Hundertmark, T.; Mayer, M.; Mcnally, C.; Simons, T.J.; Witte, C. How plastics-waste recycling could transform the chemical industry. Mckinsey Chem. 2018, 29, 118.

118. Ügdüler, S.; van Geem, K.M.; Denolf, R.; Roosen, M.; Mys, N.; Ragaert, K.; de Meester, S. Towards closed-loop recycling of multilayer and coloured pet plastic waste by alkaline hydrolysis. Green Chem. 2020, 22, 5376-5394. [CrossRef]

119. Knott, B.C.; Erickson, E.; Allen, M.D.; Gado, J.E.; Graham, R.; Kearns, F.L.; Pardo, I.; Topuzlu, E.; Anderson, J.J.; Austin, H.P.; et al. characterization and engineering of a two-enzyme system for plastics depolymerization. Proc. Natl. Acad. Sci. USA 2020, 117, 25476-25485. [CrossRef]

120. Tournier, V.; Topham, C.M.; Gilles, A.; David, B.; Folgoas, C.; Moya-Leclair, E.; Kamionka, E.; Desrousseaux, M.L.; Texier, H.; Gavalda, S.; et al. An engineered pet depolymerase to break down and recycle plastic bottles. Nature 2020, 580, 216-219. [CrossRef]

121. Kaabel, S.; Therien, J.P.D.; Deschenes, C.; Duncan, D.; Friscic, T.; Auclair, K. Clean enzymatic depolymerization of highly crystalline polyethylene terephthalate in moist-solid reaction mixtures. BioRxiv 2020, 29, 118. [CrossRef]

122. Lee, H.L.; Chiu, C.W.; Lee, T. Engineering terephthalic acid product from recycling of pet bottles waste for downstream operations. Chem. Eng. J. Adv. 2021, 5, 100079. [CrossRef]

123. Bäckström, E.; Odelius, K.; Hakkarainen, M. Ultrafast microwave assisted recycling of pet to a family of functional precursors and materials. Eur. Polym. J. 2021, 151, 110441. [CrossRef]

124. Pham, D.D.; Cho, J. Low-energy catalytic methanolysis of poly(ethyleneterephthalate). Green Chem. 2021, 23, 511-525. [CrossRef]

125. Meng, G.; Ji, K.; Zhang, W.; Kang, Y.; Wang, Y.; Zhang, P.; Wang, Y.G.; Li, J.; Cui, T.; Sun, X.; et al. Tandem catalyzing the hydrodeoxygenation of 5-hydroxymethylfurfural over a ni3fe intermetallic supported pt single-atom site catalyst. Chem. Sci. 2021, 12, 4139-4146. [CrossRef]

126. Fuentes, C.A.; Gallegos, M.v.; García, J.R.; Sambeth, J.; Peluso, M.A. Catalytic glycolysis of poly(ethylene terephthalate) using zinc and cobalt oxides recycled from spent batteries. Waste Biomass Valorization 2020, 11, 4991-5001. [CrossRef]

127. Lalhmangaihzuala, S.; Laldinpuii, Z.; Lalmuanpuia, C.; Vanlaldinpuia, K. glycolysis of poly(ethylene terephthalate) using biomass-waste derived recyclable heterogeneous catalyst. Polymers 2021, 13, 37. [CrossRef] [PubMed]

128. Liu, M.; Guo, J.; Gu, Y.; Gao, J.; Liu, F.; Yu, S. Pushing the limits in alcoholysis of waste polycarbonate with dbu-based ionic liquids under metal- and solvent-free conditions. ACS Sustain. Chem. Eng. 2018, 6, 13114-13121. [CrossRef]

129. Barnard, E.; Rubio Arias, J.J.; Thielemans, W. Chemolytic depolymerisation of PET: A Review. Green Chem. 2021, 23, 3765-3789. [CrossRef]

130. Čolnik, M.; Knez, Ž.; Škerget, M. Sub- and supercritical water for chemical recycling of polyethylene terephthalate waste. Chem. Eng. Sci. 2021, 233, 116389. [CrossRef]

131. Stanica-Ezeanu, D.; Matei, D. Natural depolymerization of waste poly(ethylene terephthalate) by neutral hydrolysis in marine water. Nat. Sci. Rep. 2021, 11, 4431. [CrossRef] [PubMed]

132. Delle Chiaie, K.R.; McMahon, F.R.; Williams, E.J.; Price, M.J.; Dove, A.P. Dual-catalytic depolymerization of polyethylene terephthalate (PET). Polym. Chem. 2020, 11, 1450-1453. [CrossRef]

133. Damayanti; Wu, H.S. Strategic possibility routes of recycled pet. Polymers 2021, 13, 1475. [CrossRef]

134. Sadler, J.C.; Wallace, S. Microbial synthesis of vanillin from waste poly(ethylene terephthalate). Green Chem. 2021, 23, 4665-4672. [CrossRef]

135. Sadeghi, B.; Marfavi, Y.; AliAkbari, R.; Kowsari, E.; Borbor Ajdari, F.; Ramakrishna, S. Recent studies on recycled pet fibers: Production and applications: A review. Mat. Circ. Econ. 2021, 3, 1-18. [CrossRef]

136. Myren, T.H.T.; Stinson, T.A.; Mast, Z.J.; Huntzinger, C.G.; Luca, O.R. Chemical and electrochemical recycling of end-use poly(ethylene terephthalate) (PET) plastics in batch, microwave and electrochemical reactors. Molecules 2020, 25, 2742. [CrossRef]

137. Du, J.T.; Sun, Q.; Zeng, X.F.; Wang, D.; Wang, J.X.; Chen, J.F. ZnO nanodispersion as pseudohomogeneous catalyst for alcoholysis of polyethylene terephthalate. Chem. Eng. Sci. 2020, 220, 115642. [CrossRef]

138. Mckeown, P.; Mckeown, P.; Kamran, M.; Kamran, M.; Davidson, M.G.; Davidson, M.G.; Jones, M.D.; Jones, M.D.; Román-Ramírez, L.A.; Wood, J. Organocatalysis for versatile polymer degradation. Green Chem. 2020, 22, 3721-3726. [CrossRef] 
139. Liu, S.; Kots, P.A.; Vance, B.C.; Danielson, A.; Vlachos, D.G. Plastic waste to fuels by hydrocracking at mild conditions. Sci. Adv. 2021, 7, 17. [CrossRef] [PubMed]

140. Jehanno, C.; Demarteau, J.; Mantione, D.; Arno, M.C.; Ruipérez, F.; Hedrick, J.L.; Dove, A.P.; Sardon, H. selective chemical upcycling of mixed plastics guided by a thermally stable organocatalyst. Angew. Chem. Int. Ed. 2021, 60, 6710-6717. [CrossRef]

141. Wang, L.; Nelson, G.A.; Toland, J.; Holbrey, J.D. Glycolysis of PET using 1,3-dimethylimidazolium-2-carboxylate as an organocatalyst. ACS Sustain. Chem. Eng. 2020, 8, 13362-13368. [CrossRef]

142. Cano, I.; Martin, C.; Fernandes, J.A.; Lodge, R.W.; Dupont, J.; Casado-Carmona, F.A.; Lucena, R.; Cardenas, S.; Sans, V.; de Pedro, I. Paramagnetic ionic liquid-coated $\mathrm{SiO}_{2} @ \mathrm{Fe}_{3} \mathrm{O}_{4}$ nanoparticles-The next generation of magnetically recoverable nanocatalysts applied in the glycolysis of PET. Appl. Catal. B 2020, 260, 118110. [CrossRef]

143. Liu, Y.; Yao, X.; Yao, H.; Zhou, Q.; Xin, J.; Lu, X.; Zhang, S. degradation of poly(ethylene terephthalate) catalyzed by metal-free choline-based ionic liquids. Green Chem. 2020, 22, 3122-3131. [CrossRef]

144. González-Izquierdo, P.; Fabelo, O.; Beobide, G.; Cano, I.; Ruiz De Larramendi, I.; Vallcorba, O.; Fernández, J.R.; Fernández-Díaz, M.T.; de Pedro, I. Crystal structure, magneto-structural correlation, thermal and electrical studies of an imidazolium halometallate molten salt: (Trimim)[FeCl ${ }_{4}$ ]. RSC Adv. 2020, 10, 11200-11209. [CrossRef]

145. Ghorbantabar, S.; Ghiass, M.; Yaghobi, N.; Bouhendi, H. investigation of conventional analytical methods for determining conversion of polyethylene terephthalate waste degradation via aminolysis process. J. Mater. Cycles Waste Manag. 2021, 23, 526-536. [CrossRef]

146. Demarteau, J.; Olazabal, I.; Jehanno, C.; Sardon, H. Aminolytic upcycling of poly(ethylene terephthalate) wastes using a thermally-stable organocatalyst. Polym. Chem. 2020, 11, 4875-4882. [CrossRef]

147. Liguori, F.; Moreno-Marrodán, C.; Barbaro, P. Valorisation of plastic waste via metal-catalysed depolymerisation. Beilstein J. Org. Chem. 2021, 17, 589-621. [CrossRef] [PubMed]

148. Taghavi, N.; Udugama, I.A.; Zhuang, W.Q.; Baroutian, S. Challenges in biodegradation of non-degradable thermoplastic waste: From environmental impact to operational readiness. Biotechnol. Adv. 2021, 49, 107731. [CrossRef] [PubMed]

149. Cornwall, W. The plastic eaters. Science 2021, 373, 36-39. [CrossRef]

150. Lee, A.; Liew, M.S. Tertiary recycling of plastics waste: An analysis of feedstock, chemical and biological degradation methods. J. Mater. Cycles Waste Manag. 2021, 23, 32-43. [CrossRef]

151. Nikolaivits, E.; Pantelic, B.; Azeem, M.; Taxeidis, G.; Babu, R.; Topakas, E.; Fournet, M.B.; Nikodinovic-Runic, J. Progressing plastics circularity: A review of mechano-biocatalytic approaches for waste plastic (re)valorization. Front. Bioeng. Biotechnol. 2021. [CrossRef] [PubMed]

152. Santacruz-Juárez, E.; Buendia-Corona, R.E.; Ramírez, R.E.; Sánchez, C. Fungal enzymes for the degradation of polyethylene: Molecular docking simulation and biodegradation pathway proposal. J. Hazard. Mater. 2021, 411. [CrossRef]

153. Scrivanti, A.; Bortoluzzi, M.; Sole, R.; Beghetto, V. Synthesis and characterization of yttrium, europium, terbium and dysprosium complexes containing a novel type of triazolyl-oxazoline ligand. Chem. Pap. 2018, 72, 799-808. [CrossRef]

154. Paganelli, S.; Alam, M.M.; Beghetto, V.; Scrivanti, A.; Amadio, E.; Bertoldini, M.; Matteoli, U. A pyridyl-triazole ligand for ruthenium and iridium catalyzed $\mathrm{C}=\mathrm{C}$ and $\mathrm{C}=\mathrm{O}$ hydrogenations in water/organic solvent biphasic systems. Appl. Catal. A-Gen. 2015, 503, 20-25. [CrossRef]

155. Beghetto, V.; Scrivanti, A.; Bertoldini, M.; Aversa, M.; Zancanaro, A.; Matteoli, U. A practical, enantioselective synthesis of the fragrances canthoxal and silvial ${ }^{2}$, and evaluation of their olfactory activity. Synthesis 2015, 47, 272-278. [CrossRef]

156. Lu, S.; Jing, Y.; Feng, B.; Guo, Y.; Liu, X.; Wang, Y. $\mathrm{H}_{2}$-free plastic conversion: Converting PET back to btx by unlocking hidden hydrogen. ChemSusChem 2021, 100514. [CrossRef]

157. Jing, Y.; Wang, Y.; Furukawa, S.; Xia, J.; Sun, C.; Hülsey, M.J.; Wang, H.; Guo, Y.; Liu, X.; Yan, N. Towards the circular economy: Converting aromatic plastic waste back to arenes over a $\mathrm{Ru} / \mathrm{Nb} 2 \mathrm{O} 5$ catalyst. Angew. Chem. Int. Ed. 2021, 60, 5527-5535. [CrossRef] [PubMed]

158. Kratish, Y.; Li, J.; Liu, S.; Gao, Y.; Marks, T.J. polyethylene terephthalate deconstruction catalyzed by a carbon-supported single-site molybdenum-dioxo complex. Angew. Chem. Int. Ed. 2020, 59, 19857-19861. [CrossRef]

159. Rorrer, J.E.; Beckham, G.T.; Román-Leshkov, Y. Conversion of polyolefin waste to liquid alkanes with ru-based catalysts under mild conditions. JACS Au 2021, 1, 8-12. [CrossRef]

160. Ellis, L.D.; Orski, S.v.; Kenlaw, G.A.; Norman, A.G.; Beers, K.L.; Román-Leshkov, Y.; Beckham, G.T. tandem heterogeneous catalysis for polyethylene depolymerization via an olefin-intermediate process. ACS Sustain. Chem. Eng. 2021, 9, 623-628. [CrossRef]

161. Kosloski-Oh, S.C.; Wood, Z.A.; Manjarrez, Y.; de Los Rios, J.P.; Fieser, M.E. Catalytic methods for chemical recycling or upcycling of commercial polymers. Mater. Horiz. 2021, 8, 1084-1129. [CrossRef]

162. Fernandes, A.C. Reductive depolymerization of plastic waste catalyzed by $\mathrm{Zn}(\mathrm{OAc})_{2} 2 \mathrm{H}_{2} \mathrm{O}$. ChemSusChem 2021, 100514. [CrossRef]

163. Dogu, O.; Pelucchi, M.; van de Vijver, R.; van Steenberge, P.H.M.; D’hooge, D.R.; Cuoci, A.; Mehl, M.; Frassoldati, A.; Faravelli, T.; van Geem, K.M. The chemistry of chemical recycling of solid plastic waste via pyrolysis and gasification: State-of-the-art, challenges, and future directions. Prog. Energy Combust. 2021, 84. [CrossRef] 
164. Miandad, R.; Rehan, M.; Barakat, M.A.; Aburiazaiza, A.S.; Khan, H.; Ismail, I.M.I.; Dhavamani, J.; Gardy, J.; Hassanpour, A.; Nizami, A.S. Catalytic pyrolysis of plastic waste: Moving toward pyrolysis based biorefineries. Front. Energy Res. $2019,7$. [CrossRef]

165. Ikäheimo, J.; Pursiheimo, E.; Kiviluoma, J.; Holttinen, H. Role of power to liquids and biomass to liquids in a nearly renewable energy system. IET Renew. Power Gener. 2019, 13, 1179-1189. [CrossRef]

166. Qureshi, M.S.; Oasmaa, A.; Pihkola, H.; Deviatkin, I.; Tenhunen, A.; Mannila, J.; Minkkinen, H.; Pohjakallio, M.; Jaine-ylijoki, J. Pyrolysis of plastic waste: Opportunities and challenges. J. Anal. Appl. Pyrol. 2020, 152. [CrossRef]

167. Su, J.; Fang, C.; Yang, M.; You, C.; Lin, Q.; Zhou, X.; Li, H. Catalytic pyrolysis of waste packaging polyethylene using alcl3-nacl eutectic salt as catalyst. J. Anal. Appl. Pyrol. 2019, 139, 274-281. [CrossRef]

168. Jia, J.; Veksha, A.; Lim, T.T.; Lisak, G. In situ grown metallic nickel from X-Ni (X=La, Mg, Sr) oxides for converting plastics into carbon nanotubes: Influence of metal-support interaction. J. Clean. Prod. 2020, 258, 120633. [CrossRef]

169. Akah, A.; Hernandez-Martinez, J.; Rallan, C.; Garforth, A. Enhanced feedstock recycling of post-consumer plastic waste. Chem. Eng. Trans. 2015, 43, 2395-2400. [CrossRef]

170. Jumah, A.B.; Tedstona, A.A.; Garforth, A. Hydrocracking of virgin and post-consumer polymers. Microporous Mesoporous Mater. 2021, 315, 110912-110920. [CrossRef]

171. Lee, W.; Bobbink, F.D.; van Muyden, A.P.; Lin, K.; Corminboeuf, C.; Zamani, R.R.; Dyson, P.J. Catalytic hydrocracking of synthetic polymers into grid-compatible gas streams. Cell Rep. 2021, 2, 100332. [CrossRef] 